\title{
Measurements of nitrogen oxides and ozone fluxes by eddy covariance at a meadow: evidence for an internal leaf resistance to $\mathrm{NO}_{2}$
}

\author{
P. Stella ${ }^{1}$, M. Kortner ${ }^{1, *}$, C. Ammann ${ }^{2}$, T. Foken ${ }^{3,4}$, F. X. Meixner ${ }^{1}$, and I. Trebs ${ }^{1}$ \\ ${ }^{1}$ Max Planck Institute for Chemistry, Biogeochemistry Department, 55020 Mainz, Germany \\ ${ }^{2}$ Agroscope ART, Air Pollution and Climate Group, 8046 Zürich, Switzerland \\ ${ }^{3}$ University of Bayreuth, Department of Micrometeorology, 95440 Bayreuth, Germany \\ ${ }^{4}$ Member of Bayreuth Center of Ecology and Environmental Research (BayCEER), Germany \\ *now at: Müller-BBM GmbH, Branch Office Frankfurt, 63589 Linsengericht, Germany
}

Correspondence to: P. Stella (patrick.stella@ mpic.de)

Received: 30 January 2013 - Published in Biogeosciences Discuss.: 7 March 2013

Revised: 26 July 2013 - Accepted: 6 August 2013 - Published: 12 September 2013

\begin{abstract}
Nitrogen dioxide $\left(\mathrm{NO}_{2}\right)$ plays an important role in atmospheric pollution, in particular for tropospheric ozone production. However, the removal processes involved in $\mathrm{NO}_{2}$ deposition to terrestrial ecosystems are still the subject of ongoing discussion. This study reports $\mathrm{NO}_{2}$ flux measurements made over a meadow using the eddy covariance method. The measured $\mathrm{NO}_{2}$ deposition fluxes during daytime were about a factor of two lower than a priori calculated fluxes using the Surfatm model without taking into account an internal (also called mesophyllic or sub-stomatal) resistance. Neither an underestimation of the measured $\mathrm{NO}_{2}$ deposition flux due to chemical divergence or an in-canopy $\mathrm{NO}_{2}$ source nor an underestimation of the resistances used to model the $\mathrm{NO}_{2}$ deposition explained the large difference between measured and modelled $\mathrm{NO}_{2}$ fluxes. Thus, only the existence of the internal resistance could account for this large discrepancy between model and measurements. The median internal resistance was estimated to be $300 \mathrm{~s} \mathrm{~m}^{-1}$ during daytime, but exhibited a large variability $\left(100-800 \mathrm{~s} \mathrm{~m}^{-1}\right)$. In comparison, the stomatal resistance was only around $100 \mathrm{~s} \mathrm{~m}^{-1}$ during daytime. Hence, the internal resistance accounted for $50-90 \%$ of the total leaf resistance to $\mathrm{NO}_{2}$. This study presents the first clear evidence and quantification of the internal resistance using the eddy covariance method; i.e. plant functioning was not affected by changes of microclimatological (turbulent) conditions that typically occur when using enclosure methods.
\end{abstract}

\section{Introduction}

Nitrogen oxides $\left(\mathrm{NO}_{\mathrm{x}}\right.$, the sum of nitric oxide, $\mathrm{NO}$, and nitrogen dioxide, $\mathrm{NO}_{2}$ ) play an important role in the photochemistry of the atmosphere. By controlling the levels of key radical species such as the hydroxyl radical $(\mathrm{OH})$, $\mathrm{NO}_{\mathrm{x}}$ are key compounds that influence the oxidative capacity of the atmosphere. In addition, $\mathrm{NO}_{\mathrm{x}}$ are closely linked with tropospheric ozone $\left(\mathrm{O}_{3}\right)$ production. $\mathrm{NO}$ is rapidly oxidized to $\mathrm{NO}_{2}$, which is photo-dissociated to $\mathrm{NO}$ and groundstate atomic oxygen $\left(\mathrm{O}\left({ }^{3} \mathrm{P}\right)\right)$ that reacts with $\mathrm{O}_{2}$ to form $\mathrm{O}_{3}$ (Crutzen, 1970, 1979). $\mathrm{O}_{3}$ is a well-known greenhouse gas responsible for positive radiative forcing, i.e. contributing to global warming, representing $25 \%$ of the net radiative forcing attributed to human activities since the beginning of the industrial era (Forster et al., 2007). Moreover, due to its oxidative capacities, $\mathrm{O}_{3}$ is also a harmful pollutant responsible for damages to materials (Almeida et al., 2000; Boyce et al., 2001), human health (Levy et al., 2005; Hazucha and Lefohn, 2007) and plants (Paoletti, 2005; Ainsworth, 2008). In natural environments, $\mathrm{O}_{3}$ may lead to biodiversity losses, while in agro-ecosystems, it induces crop yield losses (Hillstrom and Lindroth, 2008; Avnery et al., 2011a, b; Payne et al., 2011). 
$\mathrm{NO}_{\mathrm{x}}$ is also responsible for the production of nitric acid and organic nitrates, both acid rain and aerosol precursors (Crutzen, 1983). In addition, it influences the formation of nitrous acid (HONO), which is an important precursor for $\mathrm{OH}$ radicals in the atmosphere.

The important impacts of $\mathrm{NO}, \mathrm{NO}_{2}$ and $\mathrm{O}_{3}$ on both atmospheric chemistry and environmental pollution require establishing the atmospheric budgets of these gases. Therefore, it is necessary (i) to identify the different sources and sinks of $\mathrm{NO}, \mathrm{NO}_{2}$ and $\mathrm{O}_{3}$, and (ii) to understand the processes governing the exchange of these compounds between the atmosphere and the biosphere. To achieve this goal, several studies were carried out in the last decades over various ecosystems to identify the underlying processes controlling the biosphere-atmosphere exchanges of NO (e.g. Meixner, 1994; Meixner et al., 1997; Ludwig et al., 2001; Laville et al., 2009; Bargsten et al., 2010), $\mathrm{NO}_{2}$ (e.g. Meixner, 1994; Eugster and Hesterberg, 1996; Hereid and Monson, 2001; Chaparro-Suarez et al., 2011; Breuninger et al., 2012), and $\mathrm{O}_{3}$ (e.g. Zhang et al., 2002; Rummel et al., 2007; Stella et al., 2011a).

It is now well established that soil biogenic NO emission depends on several factors, such as the amount of soil moisture, soil temperature, and soil nitrogen (Remde et al., 1989; Remde and Conrad, 1991; Ludwig et al., 2001; Laville et al., 2009). Ozone is deposited to terrestrial ecosystems through dry deposition (Fowler et al., 2009). The different $\mathrm{O}_{3}$ deposition pathways are well identified and the variables controlling each pathway are well understood: the cuticular and soil ozone deposition pathways are governed by canopy structure (canopy height, leaf area index) and relative humidity at the leaf and soil surface (Zhang et al., 2002; Altimir et al., 2006; Lamaud et al., 2009; Stella et al., 2011a), while stomatal ozone flux is controlled by climatic variables responsible for stomata opening such as radiation, temperature and vapour pressure deficit (Emberson et al., 2000; Gerosa et al., 2004).

However, the processes governing the $\mathrm{NO}_{2}$ exchange between the atmosphere and the biosphere still remain unclear. While it is well recognized that $\mathrm{NO}_{2}$ is mainly deposited through stomata, with the cuticular and soil fluxes being insignificant deposition pathways for $\mathrm{NO}_{2}$ (Rondón et al., 1993; Segschneider et al., 1995; Pilegaard et al., 1998; Geßler et al., 2000; Ludwig et al., 2001), the existence of an internal resistance (also called mesophyllic or sub-stomatal resistance in previous studies) limiting $\mathrm{NO}_{2}$ stomatal uptake is still under discussion. Previous studies reported contrasting results: Segschneider et al. (1995) and Geßler et al. $(2000,2002)$ did not find an internal resistance for sunflower, beech and spruce, whereas the results obtained by Sparks et al. (2001) and Teklemariam and Sparks (2006) for herbaceous plant species and tropical wet forest suggested its existence. In addition, the importance of this internal resistance for the overall $\mathrm{NO}_{2}$ sink is not well established. Current estimates range from 3 to $60 \%$ of the total resistance to $\mathrm{NO}_{2}$ uptake (Johansson, 1987; Gut et al., 2002;
Chaparro-Suarez et al., 2011). Nevertheless, all the previous studies explored the processes of $\mathrm{NO}_{2}$ exchange using enclosure (chamber) methods under field or controlled conditions, which may affect the microclimatological conditions around the plant leaves. This issue is of particular concern since the biochemical processes probably responsible for the internal resistance are linked with leaf functioning (Eller and Sparks, 2006; Hu and Sun, 2010). In addition, the aerodynamic resistance and the quasi-laminar boundary layer resistance above the plant leaves may be modified when applying enclosure methods.

In this study we present results of the SALSA campaign (SALSA: German acronym for "contribution of nitrous acid (HONO) to the atmospheric $\mathrm{OH}$ budget"; for details see Mayer et al., 2008). Turbulent fluxes of $\mathrm{NO}, \mathrm{NO}_{2}$ and $\mathrm{O}_{3}$ were measured at a meadow below the Meteorological Observatory Hohenpeissenberg (MOHp) using the eddy covariance method. These measurements were accompanied by a comprehensive micrometeorological setup involving vertical profiles of trace gases and temperature as well as by eddy covariance measurements of carbon dioxide $\left(\mathrm{CO}_{2}\right)$ and water vapour fluxes. In the present work, (i) the influence of chemical divergence was estimated above and within the canopy, (ii) the existence of an $\mathrm{NO}_{2}$ compensation point mixing ratio was explored, (iii) the impact of the soil resistance to modelled $\mathrm{NO}_{2}$ deposition was discussed and (iv) the internal resistance for $\mathrm{NO}_{2}$ was quantified in order to understand the processes governing the $\mathrm{NO}_{2}$ exchange.

\section{Materials and methods}

\subsection{Site description}

The field study was made at a meadow in the complex landscape around Hohenpeißenberg (southern Germany) within the framework of the SALSA campaign (see Mayer et al., 2008; Trebs et al., 2009). The site consists in a managed and fertilized meadow located at the gentle lower (743 m a.s.1.) WSW slope $\left(3-4^{\circ}\right)$ of the mountain Hoher Peißenberg (summit $988 \mathrm{~m}$ a.s.l.), directly west of the village Hohenpeißenberg in Bavaria, southern Germany (coordinates: $47^{\circ} 48^{\prime} \mathrm{N}$, $\left.11^{\circ} 02^{\prime} \mathrm{E}\right)$. The surrounding pre-alpine landscape is characterized by its glacially shaped, hilly relief and a patchy land use dominated by the alternation of cattle pastures, meadows, mainly coniferous forests and rural settlements. The meadow is growing on clay-rich soil that can be classified as gley-colluvium with very small patches of marsh soil. Furthermore, it was characterized by its relatively low plant biodiversity and consisted mainly of perennial ryegrass (Lolium perenne L.), ribwort (Plantago lanceolata L.), dandelion (Taraxacum officinale), red clover (Trifolium pratense L.), white clover (Trifolium repens L.), common cow parsnip (Heracleum sphondylium L.), sour dock (Rumex acetosa 
L.), daisy (Bellis perennis L.), and cow parsley (Anthriscus sylvestris (L.) Hoffm.).

The experiment was carried out from 29 August to 20 September 2005. The meadow was mown just before the instrument setup. The canopy height $\left(h_{\mathrm{c}}\right)$ and leaf area index (LAI) increased from $15 \mathrm{~cm}$ and $2.9 \mathrm{~m}^{2} \mathrm{~m}^{-2}$ (at the beginning of the campaign) to $25 \mathrm{~cm}$ and $4.9 \mathrm{~m}^{2} \mathrm{~m}^{-2}$ at the end of the experiment, respectively. The roughness length $\left(z_{0}=0.1\right.$ $h_{\mathrm{c}}$ ) ranged from 1.5 to $2.5 \mathrm{~cm}$ and the displacement height $\left(d=0.7 h_{\mathrm{c}}\right)$ varied between 10.5 and $17.5 \mathrm{~cm}$. These values were confirmed by estimates of $z_{0}$ and $d$ from flux and profile records for 10-15 September.

The setup consisted of five measurement stations, (all located in an area of $400 \mathrm{~m}^{2}$, with a distance of $20-30 \mathrm{~m}$ to each other). The stations recorded meteorological conditions ("MET 1" and "MET 2" from the Bayreuth University (UBT) and the Max Planck Institute for Chemistry (MPIC), respectively), mixing ratio profiles ("PROFILE" from the MPIC) and turbulent fluxes ("EC 1" and "EC 2" from the UBT and the MPIC, respectively) (see Table 1). The detailed measurement setups are described in Table 1 and the following sections.

\subsection{Meteorological measurements}

The following standard meteorological variables (and vertical profiles) were recorded: global radiation $\left(G_{\mathrm{r}}\right)$ and net radiation, relative humidity $(\mathrm{RH})$, air temperature $\left(T_{\mathrm{a}}\right)$, wind speed $(u)$ and direction, and rainfall. The photolysis rate of $\mathrm{NO}_{2}\left(j_{\mathrm{NO}_{2}}\right)$, soil temperature $\left(T_{\text {soil }}\right)$ and soil water content (SWC) were also measured (for details see Table 1).

\subsection{Trace gas profile measurements}

Profile measurements of $\mathrm{NO}, \mathrm{O}_{3}$, and $\mathrm{NO}_{2}$ mixing ratios were made in order to investigate the chemistry of the NO$\mathrm{O}_{3}-\mathrm{NO}_{2}$ triad above and within the canopy. The profile system consisted of six measurement levels: one inside the canopy $(0.05 \mathrm{~m}$ above ground level), one at the canopy top (first in $0.20 \mathrm{~m}$, later moved to $0.28 \mathrm{~m}$ ), and four above the canopy $(0.50,1.00,1.65$ and $3.00 \mathrm{~m})$. The $\mathrm{NO}, \mathrm{O}_{3}$, and $\mathrm{NO}_{2}$ analysers were located in an air-conditioned container about $60 \mathrm{~m}$ northeast from the air inlets. The profile system was described previously by Mayer et al. (2011). Briefly, air samples from all heights were analysed by the same analyser consecutively and the levels were switched automatically by a valve system directly in front of a Teflon ${ }^{\circledR}$ diaphragm pump. The length of the opaque inlet lines made of PFA (perfluoroalkoxy copolymer) ranged from 62 to $65 \mathrm{~m}$ (depending on the sampling height). All non-active tubes were continuously flushed by a bypass pump. To avoid condensation of water vapour inside the tubes, they were insulated and heated to a few degrees above ambient temperature. Pressure and temperature in the tubes were monitored continuously. The individual heights were sampled with different frequencies: ambient air from the inlet levels at 0.50 and $1.65 \mathrm{~m}$ were sampled ten times, other levels five times per $60 \mathrm{~min}$ (with each interval consisting of three individually recorded $30 \mathrm{~s}$ subintervals). Data from the first $30 \mathrm{~s}$ interval at each level were discarded to take into account the equilibration time of tubing and analysers. Measured mixing ratios were corrected for the gas-phase chemistry during the residence time of the air inside the sampling system according to Beier and Schneewind (1991).

NO was measured by red-filtered detection of chemiluminescence - generated by the $\mathrm{NO}+\mathrm{O}_{3}$ reaction - with a CLD 780TR (EcoPhysics, Switzerland). Excess $\mathrm{O}_{3}$ was frequently added in the pre-reaction chamber to account for interference of other trace gases. For the conversion of $\mathrm{NO}_{2}$ to detectable NO, photolysis is the most specific technique (Kley and McFarland, 1980; Ridley et al., 1988). Thus, $\mathrm{NO}_{2}$ in ambient air was photolytically converted to NO by directing every air sample air through a blue light converter (BLC, Droplet Measurement Technologies Inc.). Here, the light source was an UV diode array, which emits radiation within a very narrow spectral band (385-405 nm), making the NO-to- $\mathrm{NO}_{2}$ conversion more specific and the conversion efficiency more stable in time than conventional converters based on photolysis of a broad spectral continuum (Pollack et al., 2011). The $\mathrm{NO}_{2}$ mixing ratio can be determined from the difference between the NO mixing ratios measured with BLC and bypassing the BLC, respectively. The NO analyser was calibrated by diluting a certified NO standard gas (5.0 ppm, Air Liquide). The detection limit of the CLD 780TR was $90 \mathrm{ppt}$ ( $3 \sigma$-definition). The efficiency of the photolytic conversion of $\mathrm{NO}_{2}$ to $\mathrm{NO}$ was determined by a back titration procedure involving the reaction of $\mathrm{O}_{3}$ with $\mathrm{NO}$ using a gas-phase titration system (Dynamic Gas Calibrator 146 C, Thermo Environmental Instruments Inc., USA). Conversion efficiencies were about $33 \%$. Ozone mixing ratios of the ambient air samples were measured by an UV absorption instrument (49 C, Thermo Environment, USA).

\subsection{Eddy covariance measurements}

Eddy covariance (EC) has been extensively used during the last decades to estimate turbulent fluxes of momentum, heat and (non-reactive) trace gases (Running et al., 1999; Aubinet et al., 2000; Baldocchi et al., 2001; Dolman et al., 2006; Skiba et al., 2009). It is a direct measurement method to determine the exchange of mass and energy between the atmosphere and terrestrial surfaces without application of any empirical constant. The theoretical background for the eddy covariance can be found in the existing literature (e.g. Foken, 2008; Foken et al., 2012a; Aubinet et al., 2012) and will not be detailed here.

The turbulent fluxes of momentum $(\tau)$, sensible $(H)$ and latent (LE) heat, $\mathrm{CO}_{2}, \mathrm{NO}, \mathrm{NO}_{2}$ and $\mathrm{O}_{3}$ were measured by two EC stations (Table 1). One station (MPIC) was dedicated to the measurement of $\mathrm{NO}-\mathrm{NO}_{2}-\mathrm{O}_{3}$ (as well as momentum 
Table 1. Overview of stations and instrumentation used during the SALSA experiment.

\begin{tabular}{|c|c|c|c|}
\hline Quantity & Station & Heights $[\mathrm{m}]$ & Instrumentation \\
\hline Global radiation & MET 1 (UBT) & 2.0 & $\begin{array}{l}\text { Pyranometer CM21, Kipp \& Zonen B.V., } \\
\text { Netherlands }\end{array}$ \\
\hline Net radiation & MET 2 (MPIC) & 2.0 & $\begin{array}{l}\text { Net radiometer NR Lite, Kipp \& Zonen } \\
\text { B.V., Netherlands }\end{array}$ \\
\hline$J_{\mathrm{NO}_{2}}$ & MET 2 (MPIC) & 2.0 & $\begin{array}{l}\text { Filter radiometer, Meteorologie Consult } \\
\text { GmbH, Königstein, Germany }\end{array}$ \\
\hline Relative humidity & MET 2 (MPIC) & 2.0 & $\begin{array}{l}\text { Hygromer®IN-1 \& Pt100 in aspirated } \\
\text { housing, Rotronic Messgeräte } \mathrm{GmbH} \text {, } \\
\text { Germany }\end{array}$ \\
\hline Air temperature & MET 2 (MPIC) & $\begin{array}{l}0.05,0.2,0.5,1.0,1.5 \\
2.0,2.5,3.0\end{array}$ & $\begin{array}{l}\text { Fine-wire thermocouples; } 1 \mathrm{~Hz} \text { time reso- } \\
\text { lution, Campbell Scientific, UK }\end{array}$ \\
\hline Wind speed & MET 2 (MPIC) & $0.2,0.5,1.0,3.0$ & $\begin{array}{l}\text { Vaisala, ultrasonic wind sensor WS } 425 \text {, } \\
\text { Finland }\end{array}$ \\
\hline Wind direction & MET 2 (MPIC) & $0.2,0.5,1.0,3.0$ & $\begin{array}{l}\text { Vaisala, ultrasonic wind sensor WS425, } \\
\text { Finland }\end{array}$ \\
\hline Rainfall & MET 2 (MPIC) & 2.0 & $\begin{array}{l}\text { Tipping rain gauge, ARG 100-EC, Camp- } \\
\text { bell Scientific, UK }\end{array}$ \\
\hline Soil temperature & MET 1 (UBT) & -0.02 & TDR sonde, IMKO, Germany \\
\hline Soil water content & MET 2 (MPIC) & -0.05 & TDR sonde, IMKO, Germany \\
\hline $\begin{array}{l}\mathrm{NO}-\mathrm{NO}_{2}-\mathrm{O}_{3} \text { mixing } \\
\text { ratio profile }\end{array}$ & PROFILE (MPIC) & $\begin{array}{l}0.05,0.20(0.28), 0.50 \\
1.0,1.65,3.0\end{array}$ & $\begin{array}{l}\text { CLD 780TR, EcoPhysics, Switzerland } \\
\text { Blue light converter, BLC, Droplet Mea- } \\
\text { surement Technologies Inc., USA } \\
\text { UV absorption instrument, } 49 \text { C, Thermo } \\
\text { Environment, USA }\end{array}$ \\
\hline $\begin{array}{l}\text { Momentum flux } \\
\text { Sensible heat flux }\end{array}$ & EC 1 (UBT) & 2.0 & $\begin{array}{l}\text { Sonic anemometer, CSAT3, Campbell Sci- } \\
\text { entific, UK }\end{array}$ \\
\hline $\begin{array}{l}\text { Latent heat flux } \\
\mathrm{CO}_{2} \text { flux }\end{array}$ & & & $\begin{array}{l}\text { Open path gas analyzer, IRGA } 7500 \text {, } \\
\text { LiCor, USA }\end{array}$ \\
\hline $\mathrm{NO}-\mathrm{NO}_{2}-\mathrm{O}_{3}$ fluxes & EC 2 (MPIC) & 2.0 & $\begin{array}{l}\text { Sonic anemometer, Solent Wind Master } \\
\text { R2, Gill Instruments, UK } \\
\text { CLD 790SR-2, EcoPhysics, Switzerland } \\
\text { blue light converter, BLC, Droplet Mea- } \\
\text { surement Technologies Inc, USA } \\
\text { OS-G2, GEFAS GmbH, Germany }\end{array}$ \\
\hline
\end{tabular}

and sensible heat, $H$ ) fluxes, while the second (UBT), located $\sim 20 \mathrm{~m}$ in the southern direction, measured momentum, $H$, $\mathrm{LE}$, and $\mathrm{CO}_{2}$ fluxes. The fetch was limited to around $50 \mathrm{~m}$ in the NW and NE sector, but extended at least to $150 \mathrm{~m}$ in all other directions. Three-dimensional wind speed and temperature fluctuations were measured by sonic anemometers (Table 1). For high-frequency $\mathrm{CO}_{2}$ and water vapour measurements an open-path infrared gas analyser (IRGA 7500, LiCor, USA) was used. High-frequency $(5 \mathrm{~Hz})$ time series of $\mathrm{NO}$ and $\mathrm{NO}_{2}$ were determined with a fast-response and highly sensitive closed-path 2-channel chemiluminescence NO analyser (CLD 790SR-2, EcoPhysics, Switzerland) coupled with a photolytic converter (blue light converter, BLC, Droplet Measurement Technologies Inc, USA) for the detection of $\mathrm{NO}_{2}$ (see Sect. 2.3). The NO detection principle of the CLD 790SR-2 is identical to that of the CLD 780TR described above. However, the sensitivity is a factor of 10 higher than that of the CLD 780TR, and due to the presence of two channels the concentrations of NO and $\mathrm{NO}_{2}$ can be measured simultaneously with high time resolution (see Hosaynali Beygi et al., 2011). The accuracy of the CLD790SR-2 is about $5 \%$ and the NO detection limit for a one-second integration time is $10 \mathrm{ppt}$ ( $3 \sigma$-definition). The instrument was also located in the air-conditioned container, about $60 \mathrm{~m}$ NE from the sonic anemometer. The trace gas inlets were fixed $33 \mathrm{~cm}$ below the sound path of the anemometer without horizontal separation at a three-pod mast. Air was sampled through two heated and opaque PFA tubes with a length of $63 \mathrm{~m}$ and an inner diameter of $4.4 \mathrm{~mm}$. While the first sample line and CLD channel was used for measuring NO, a BLC was placed just behind the sample inlet of the second channel in a ventilated housing mounted at a boom of the measurement mast. Despite the low volume of the BLC $(17 \mathrm{~mL})$, conversion efficiencies $\gamma$ for $\mathrm{NO}_{2}$ to $\mathrm{NO}$ of around $41 \%$ were achieved. Consequently this channel detected a 
partial $\mathrm{NO}_{\mathrm{x}}$ signal (denoted here as $\mathrm{NO}_{\mathrm{x}}^{*}$ ) corresponding to

$\chi\left\{\mathrm{NO}_{\mathrm{x}}^{*}\right\}=\chi\{\mathrm{NO}\}+\gamma \cdot \chi\left\{\mathrm{NO}_{2}\right\}$.

Flow restrictors for both channels of the CLD790SR-2 were mounted into the tubing closely after the corresponding inlets (after the BLC in the second channel) in order to achieve short residence times of the air samples inside the tubing $\left(9 \pm 0.4 \mathrm{~s}\right.$ and $13 \pm 0.4 \mathrm{~s}$ for $\mathrm{NO}$ and $\mathrm{NO}_{2}$, respectively) and fully turbulent conditions. The EC fluxes for the two analyser channels were first calculated independently and the $\mathrm{NO}_{2}$ flux was then determined as

$F_{\mathrm{NO}_{2}}=\frac{1}{\gamma} \cdot\left(F_{\mathrm{NO}_{\mathrm{X}}}{ }-F_{\mathrm{NO}}\right)$.

Simultaneously, eddy covariance fluxes of $\mathrm{O}_{3}$ were measured with a surface chemiluminescence instrument (Table 1) (Güsten et al., 1992; Güsten and Heinrich, 1996), which was mounted on the three-pod mast with its inlet mounted directly next to that of $\mathrm{NO}$ and $\mathrm{NO}_{2}$.

The $5 \mathrm{~Hz}$ signals of both CLD790SR-2 channels, referenced to the frequently calibrated $\mathrm{NO}$ and $\mathrm{NO}_{2}$ measurements at $1.65 \mathrm{~m}$ from the trace gas profile system, were used for the final calculation of $\mathrm{NO}$ and $\mathrm{NO}_{2}$ fluxes for $30 \mathrm{~min}$ time intervals. The $\mathrm{O}_{3}$ flux calibration was done according to Müller et al. (2010). The quality of the derived fluxes was evaluated with the quality assessment schemes of Foken and Wichura (1996) (see also Foken et al., 2004), which validate the development state of turbulence by comparing the measured integral turbulence characteristics. Flux calculations included despiking of scalar time series (Vickers and Mahrt, 1997), planar fit coordinate rotation (Wilczak et al., 2001), linear detrending, correction of the time lag induced by the $63 \mathrm{~m}$ inlet tube, and correction for flux losses due to the attenuation of high-frequency contributions according to Spirig et al. (2005) based on ogive analysis (Oncley, 1989; Desjardins et al., 1989). The high-frequency losses were typically $12-20 \%$ for NO, 16-25\% for $\mathrm{NO}_{2}$ and 6-8 \% for $\mathrm{O}_{3}$. Since pressure and temperature were held constant by the instruments and the effect of water vapour fluctuations was negligible, corrections for density fluctuations (WPL corrections, Webb et al., 1980) were not necessary for $\mathrm{NO}, \mathrm{NO}_{2}$ and $\mathrm{O}_{3}$.

\subsection{Soil NO emission from laboratory}

A composite soil sample ( $0-5 \mathrm{~cm}$ depth) was taken from the Hohenpeißenberg meadow site at the end of September 2005, and biogenic NO emission of the meadow soil was subsequently quantified in the soil laboratory of MPIC. Applying a method which is described in full detail by Feig et al. (2008) and Bargsten et al. (2010), sub-samples (80 g) of the composite soil sample were sieved through a $2 \mathrm{~mm}$ mesh and were incubated (at soil temperatures of 15 and $25^{\circ} \mathrm{C}$ ) and fumigated (with zero and $58 \mathrm{ppb} \mathrm{NO}$ ) over the full range of 0.05 to 0.6 gravimetric soil moisture (in steps of 0.002 ). These laboratory studies resulted in the determination of the so-called net potential soil NO flux as function of soil temperature and moisture. From that, the actual surface net NO flux of the meadow soil is calculated using soil temperature ( $2 \mathrm{~cm}$ depth) and soil moisture $(5 \mathrm{~cm}$ depth) data obtained by continuous measurements at the meadow site during the field experiment.

\subsection{Resistance model parameterizations}

The transfer of heat and trace gases can be assimilated into a resistance network with analogy to Ohm's law (Wesely, 1989; Wesely and Hicks, 2000). It includes the turbulent resistance above $\left(R_{\mathrm{a}}\right)$ and within $\left(R_{\mathrm{ac}}\right)$ the canopy, the quasilaminar boundary layer $\left(R_{\mathrm{b}}\right)$, the stomatal $\left(R_{\mathrm{S}}\right)$ and internal $\left(R_{\text {int }}\right)$ resistances, the cuticular resistance $\left(R_{\text {cut }}\right)$ and the soil resistance $\left(R_{\text {soil }}\right)$.

In order to investigate the processes governing the exchanges of $\mathrm{NO}_{2}$ and $\mathrm{O}_{3}$, we used the Surfatm model developed to simulate exchanges of heat and pollutant between the atmosphere and the vegetation (Personne et al., 2009; Stella et al., 2011b). It is a multi-resistance soil-vegetationatmosphere transfer (SVAT) model which couples (i) a trace gas exchange model and (ii) an energy budget model allowing to estimate the temperature and humidity of the leaves and of the soil to calculate the resistances to trace gas exchange. It comprises one vegetation layer and one soil layer. This model was initially developed to simulate the ammonia exchange, it was validated over grasslands by Personne et al. (2009), and it was recently adapted to estimate $\mathrm{O}_{3}$ deposition to several maize crops by Stella et al. (2011b). In the following, we will only focus on the specific resistances to $\mathrm{NO}_{2}$ and $\mathrm{O}_{3}$ deposition. However, more details and explanations concerning the resistive scheme and the resistance parameterizations can be found in Personne et al. (2009) and Stella et al. (2011b).

The resistive scheme for $\mathrm{NO}_{2}$ and $\mathrm{O}_{3}$ deposition is shown in Fig. 1. Turbulent resistances above and within the canopy are identical for both $\mathrm{NO}_{2}$ and $\mathrm{O}_{3}$, and were expressed as

$$
\begin{aligned}
R_{\mathrm{a}}\left(z_{\text {ref }}\right) & =\frac{1}{k^{2} \cdot u\left(z_{\text {ref }}\right)} \cdot\left\{\ln \left(\frac{z_{\text {ref }}-d}{z_{0 T}}\right)-\Psi_{H}\left(\left(z_{\text {ref }}-d\right) / L\right)\right\} \\
& \cdot\left\{\ln \left(\frac{z_{\text {ref }}-d}{z_{0 M}}\right)-\Psi_{M}\left(\left(z_{\text {ref }}-d\right) / L\right)\right\}
\end{aligned}
$$

$$
R_{\mathrm{ac}}=\frac{h_{\mathrm{c}} \cdot \exp \left(\alpha_{u}\right)}{\alpha_{u} \cdot K_{M}\left(h_{\mathrm{c}}\right)} \cdot\left\{\exp \left(\frac{-\alpha_{u} \cdot z_{0 s}}{h_{\mathrm{c}}}\right)-\exp \left(\frac{-\alpha_{u} \cdot\left(d+z_{0 M}\right)}{h_{\mathrm{c}}}\right)\right\},
$$

where $k(=0.4)$ is the von Kármán constant; $z_{\text {ref }}$ is the reference height; $d$ is the displacement height; $z_{0 T}$ and $z_{0 M}$ are the canopy roughness length for temperature and momentum, respectively; $z_{0 s}(=0.02 \mathrm{~m}$; Personne et al., 2009) is the ground surface roughness length below the canopy; $h_{\mathrm{c}}$ is the canopy height; $u\left(z_{\text {ref }}\right)$ is the wind speed at $z_{\text {ref }} ; \alpha_{u}(=4.2)$ is the attenuation coefficient for the decrease of the wind speed 


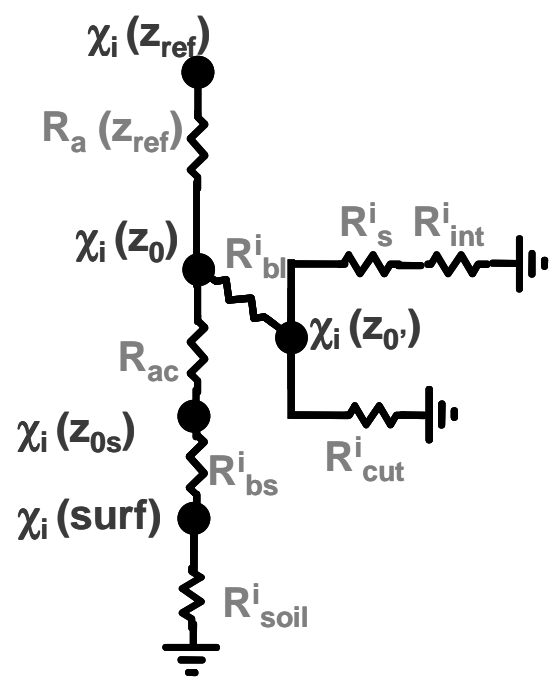

Fig. 1. Resistive scheme used in the Surfatm model for pollutant exchange. $\chi$ is the gas concentration. $R_{\mathrm{a}}, R_{\mathrm{ac}}, R_{\mathrm{bl}}, R_{\mathrm{bs}}, R_{\mathrm{S}}, R_{\mathrm{int}}$, $R_{\text {cut }}$ and $R_{\text {soil }}$ are aerodynamic resistance above the canopy, aerodynamic resistance within the canopy, leaf quasi-laminar boundary layer resistance, soil quasi-laminar boundary layer resistance, stomatal resistance, internal resistance, cuticular resistance and soil resistance, respectively. Indexes $i, z_{\text {ref }}, z_{0}, z_{0^{\prime}}, z_{0 s}$ and "surf" indicate the gas considered, the reference height, the canopy roughness height for momentum, the canopy roughness height for scalar, the soil roughness height for momentum, and the soil surface, respectively.

inside the canopy (Raupach et al., 1996); $K_{M}\left(h_{\mathrm{c}}\right)$ is the eddy diffusivity at the canopy height; and $\Psi_{M}\left(\left(z_{\text {ref }}-d\right) / L\right)$ and $\Psi_{H}\left(\left(z_{\text {ref }}-d\right) / L\right)$ are dimensionless stability correction functions for momentum and heat, respectively (Dyer and Hicks, 1970).

The canopy $\left(R_{\mathrm{bl}}\right)$ and soil $\left(R_{\mathrm{bs}}\right)$ quasi-laminar boundary layer resistances depend on the trace gas $i$ considered and were expressed following Shuttelworth and Wallace (1985) and Choudhury and Monteith (1988), and Hicks et al. (1987), respectively, as

$R_{\mathrm{bl}}^{i}=\frac{D_{i}}{D_{\mathrm{H}_{2} \mathrm{O}}} \cdot \frac{\alpha_{u}}{2 \cdot a \cdot \mathrm{LAI}} \cdot\left(\frac{L W}{u\left(h_{\mathrm{c}}\right)}\right)^{0.5} \cdot\left\{1-\exp \left(-\frac{\alpha_{u}}{2}\right)\right\}^{-1}$

$R_{\mathrm{bs}}^{i}=\frac{2}{k \cdot u_{* \text { ground }}} \cdot\left(\frac{\mathrm{Sc}_{i}}{\operatorname{Pr}}\right)^{2 / 3}$

where $a$ is a coefficient equal to $0.01 \mathrm{~s} \mathrm{~m}^{-1 / 2}$ (Choudhury and Monteith, 1988); LW $(=0.05 \mathrm{~m})$ is the characteristic width of the leaves; $D_{i}$ and $D_{\mathrm{H}_{2} \mathrm{O}}$ are the diffusivities of the gas $i$ and water vapour, respectively $\left(D_{\mathrm{O}_{3}} / D_{\mathrm{H}_{2} \mathrm{O}}=0.66\right.$ and $D_{\mathrm{NO}_{2}} / D_{\mathrm{H}_{2} \mathrm{O}}=0.62$; Massman, 1998); $\mathrm{Sc}_{i}$ and $\mathrm{Pr}$ are the Schmidt number for the gas $i$ and the Prandtl number $\left(\left(\mathrm{Sc}_{\mathrm{O}_{3}} / \mathrm{Pr}\right)^{2 / 3}=1.14\right.$ for $\mathrm{O}_{3}$ and $\left(\mathrm{Sc}_{\mathrm{NO}_{2}} / \mathrm{Pr}\right)^{2 / 3}=1.19$ for $\mathrm{NO}_{2}$; Erisman et al., 1994); and $u_{* \text { ground }}$ is the friction velocity near the soil surface calculated following Loubet et al. (2006) as

$u_{* \text { ground }}=\left\{\left(u^{*}\right)^{2} \cdot \exp \left(1.2 \cdot \mathrm{LAI} \cdot\left(\frac{z_{0 s}}{h_{\mathrm{c}}}-1\right)\right)\right\}^{0.5}$,

where $u_{*}$ is the friction velocity above the canopy.

The stomatal resistance was not modelled but used as input. It was inferred from water vapour flux measurements by inverting the Penman-Monteith equation (Monteith, 1981):

$R_{\mathrm{SPM}}^{i}=\left\{\frac{D_{i}}{D_{\mathrm{H}_{2} \mathrm{O}}} \cdot \frac{\frac{E}{\delta_{\mathrm{w}}}}{1+\frac{E}{\delta_{\mathrm{w}}} \cdot\left(R_{\mathrm{a}}+R_{\mathrm{b}}^{i}\right) \cdot\left(\frac{\beta \cdot s}{\gamma}-1\right)}\right\}^{-1}$,

where $E$ is the water vapour flux $\left(\mathrm{kg} \mathrm{m}^{-2} \mathrm{~s}^{-1}\right), \delta_{\mathrm{w}}$ the water vapour density saturation deficit $\left(\mathrm{kg} \mathrm{m}^{-3}\right), \beta$ the Bowen ratio, $s$ the slope of the saturation curve $\left(\mathrm{K}^{-1}\right)$ and $\gamma$ the psychrometric constant $\left(\mathrm{K}^{-1}\right)$. However, $R_{\mathrm{SPM}}$ can be defined as the stomatal resistance if $E$ represents plant transpiration only; i.e. the influence of soil evaporation and evaporation of liquid water (rain, dew) that may be present at the canopy surface has to be excluded. Thus, our estimation of stomatal resistance was corrected for water evaporation as proposed by Lamaud et al. (2009): for dry conditions ( $\mathrm{RH}<60 \%$, for which liquid water at the leaf surface is considered to be completely evaporated) $R_{\mathrm{SPM}}$ was plotted against gross primary production (GPP, estimated on a daily basis following Kowalski et al., 2003, 2004). The corrected stomatal resistance $\left(R_{\mathrm{S}}\right)$ for all humidity conditions is then given by

$R_{\mathrm{s}}^{i}=\frac{D_{i}}{D_{\mathrm{H}_{2} \mathrm{O}}} \alpha \cdot \mathrm{GPP}^{\lambda}$,

where $\alpha(=7465)$ and $\lambda(=-1.6)$ are coefficients given by the regression between $R_{\mathrm{SPM}_{\mathrm{PM}}}$ and GPP under dry conditions.

The soil and cuticular resistances to $\mathrm{O}_{3}$ deposition were expressed following Stella et al. (2011a, b) as

$R_{\text {soil }}^{\mathrm{O}_{3}}=R_{\text {soil }_{\text {min }}} \cdot \exp \left(k_{\text {soil }} \cdot \mathrm{RH}_{\text {surf }}\right)$

$R_{\text {cut }}^{\mathrm{O}_{3}}=R_{\text {cut }_{\text {max }}} \quad$ if $\quad \mathrm{RH}_{z^{\prime} 0}<\mathrm{RH}_{0}$

$$
\begin{aligned}
& R_{\text {cut }}^{\mathrm{O}_{3}}=R_{\mathrm{cut}_{\max }} \cdot \exp \left(-k_{c u t} \cdot\left(\mathrm{RH}_{z_{0}^{\prime}}-\mathrm{RH}_{0}\right)\right), \\
& \quad \text { if } \mathrm{RH}_{z^{\prime} 0}>\mathrm{RH}_{0}
\end{aligned}
$$

where $R_{\text {soil }_{\text {min }}}\left(=21.15 \mathrm{~s} \mathrm{~m}^{-1}\right)$ is the soil resistance without water adsorbed at the soil surface (i.e. at $\mathrm{RH}_{\text {surf }}=0 \%$ ), $k_{\text {soil }}(=0.024)$ is an empirical coefficient of the exponential function, $R_{\text {cut }_{\max }}(=5000 / \mathrm{LAI})$ is the maximal cuticular resistance calculated according to Massman (2004), $\mathrm{RH}_{0}$ $(=60 \%)$ is a threshold value of the relative humidity, $k_{\text {cut }}$ 
$(=0.045)$ is an empirical coefficient of the exponential function taken from Lamaud et al. (2009), and $\mathrm{RH}_{\text {surf }}$ and $\mathrm{RH}_{z^{\prime} 0}$ are the relative humidity at the soil and leaf surface, respectively, calculated by the energy balance model.

Concerning the $\mathrm{NO}_{2}$ cuticular resistance, several studies have shown that this deposition pathway did not contribute significantly to $\mathrm{NO}_{2}$ deposition and could be neglected (Rondón et al., 1993; Segschneider et al., 1995; Gut et al., 2002). Consequently, $R_{\mathrm{cut}}^{\mathrm{NO}_{2}}$ was set to $9999 \mathrm{~s} \mathrm{~m}^{-1}$. Since an empirical parameterization for the soil resistance to $\mathrm{NO}_{2}$ deposition is currently not available, a constant value $\left(R_{\mathrm{soil}}^{\mathrm{NO}_{2}}=340 \mathrm{~s} \mathrm{~m}^{-1}\right)$ reported by Gut et al. (2002) for a soil in the Amazonian rain forest was used.

Finally, many trace gases entering into plants through stomata can react with compounds in the sub-stomatal cavity and the mesophyll. For $\mathrm{O}_{3}$, there is evidence that $R_{\text {int }}$ is usually zero (Erisman et al., 1994). However, for $\mathrm{NO}_{2}$ there is currently no consensus concerning the existence of an internal resistance, and the uncertainty of the magnitude of its contribution to the overall surface resistance is large. Due to this insufficient knowledge, $R_{\text {int }}$ was also set to zero for $\mathrm{NO}_{2}$ in the "a priori" model parameterization.

The total deposition flux of the scalar $i\left(F_{i}\right)$ is the sum of deposition flux to the soil $\left(F_{\text {soil }}^{i}\right)$ and the deposition flux to the vegetation $\left(F_{\mathrm{veg}}^{i}\right)$ :

$F_{i}=F_{\text {soil }}^{i}+F_{\text {veg }}^{i}$.

In analogy to Ohm's law and following the resistive scheme of the Surfatm model (Fig. 1), total, vegetation and soil fluxes can be expressed as

$$
\begin{aligned}
& F_{i}=\frac{\chi_{i}\left(z_{0}\right)-\chi_{i}\left(z_{\mathrm{ref}}\right)}{R_{\mathrm{a}}\left(z_{\mathrm{ref}}\right)} \\
& F_{\mathrm{veg}}^{i}=\frac{-\chi_{i}\left(z_{0}\right)}{R_{\mathrm{bl}}^{i}+\left[\frac{1}{R_{\mathrm{cut}}^{i}}+\frac{1}{R_{\mathrm{s}}^{i}+R_{\mathrm{int}}^{i}}\right]^{-1}} \\
& F_{\mathrm{soil}}^{i}=\frac{-\chi_{i}\left(z_{0}\right)}{R_{\mathrm{ac}}+R_{\mathrm{bs}}^{i}+R_{\mathrm{soil}}^{i}} .
\end{aligned}
$$

The deposition flux to soil can also be expressed as

$$
\begin{aligned}
& F_{\text {soil }}^{i}=\frac{\chi_{i}\left(z_{0 s}\right)-\chi_{i}\left(z_{0}\right)}{R_{\mathrm{ac}}} \\
& F_{\text {soil }}^{i}=\frac{-\chi_{i}\left(z_{0 s}\right)}{R_{\mathrm{bs}}^{i}+R_{\mathrm{soil}}^{i}} .
\end{aligned}
$$

\subsection{Chemical reactions and transport times}

In contrast to inert gases such as $\mathrm{CO}_{2}$ and $\mathrm{H}_{2} \mathrm{O}$, the fluxes of $\mathrm{NO}, \mathrm{NO}_{2}$ and $\mathrm{O}_{3}$ could be subject to chemical reactions leading to non-constant fluxes with height (vertical flux divergence). According to Remde et al. (1993) and Warneck (2000), the main gas-phase reactions for the $\mathrm{NO}^{-} \mathrm{O}_{3}-$ $\mathrm{NO}_{2}$ triad are

$\mathrm{NO}+\mathrm{O}_{3} \stackrel{k_{\mathrm{r}}}{\longrightarrow} \mathrm{NO}_{2}+\mathrm{O}_{2}$

$\mathrm{NO}_{2}+\mathrm{O}_{2}+h v \stackrel{j_{\mathrm{NO} 2}}{\longrightarrow} \mathrm{NO}+\mathrm{O}_{3}$,

where $k_{\mathrm{r}}$ is the rate constant of R1 (Atkinson et al., 2004) and $j_{\mathrm{NO} 2}$ is the photolysis frequency for $\mathrm{R} 2$.

The chemical reaction time for the $\mathrm{NO}-\mathrm{O}_{3}-\mathrm{NO}_{2}$ triad ( $\tau_{\text {chem }}$ in s) gives the characteristic timescale of the set of $\mathrm{R} 1$ and R2. It was estimated following the approach of Lenschow (1982):

$$
\begin{aligned}
\tau_{\text {chem }}= & 2 /\left[j_{\mathrm{NO}_{2}}{ }^{2}+k_{\mathrm{r}}^{2} \cdot\left(\mathrm{O}_{3}-\mathrm{NO}\right)^{2}+2 \cdot j_{\mathrm{NO}_{2}} \cdot k_{\mathrm{r}} .\right. \\
& \left.\left(\mathrm{O}_{3}+\mathrm{NO}+2 \cdot \mathrm{NO}_{2}\right)\right]^{0.5}
\end{aligned}
$$

In addition, the characteristic chemical depletion times for $\mathrm{NO}, \mathrm{O}_{3}$ and $\mathrm{NO}_{2}$ were calculated according to De Arellano and Duynkerke (1992):

$$
\begin{aligned}
& \tau_{\text {depl NO }}=\frac{1}{k_{\mathrm{r}} \cdot \mathrm{O}_{3}} \\
& \tau_{\text {depl } \mathrm{O}_{3}}=\frac{1}{k_{\mathrm{r}} \cdot \mathrm{NO}} \\
& \tau_{\mathrm{deplNO}_{2}}=\frac{1}{j_{\mathrm{NO}_{2}}} .
\end{aligned}
$$

The comparison of characteristic chemical reaction times with characteristic turbulent transport times indicates whether or not there is a significant vertical divergence of the turbulent flux of reactive trace gases. The transport time ( $\tau_{\text {trans }}$ in $s$ ) in one layer (i.e. above the canopy, between the measurement height and the canopy top, or within the canopy) can be expressed as the aerodynamic resistance through each layer multiplied by the layer thickness (Garland, 1977):

$\tau_{\text {trans }}=R_{\mathrm{a}}\left(z_{\text {ref }}\right) \cdot\left(z_{\text {ref }}-d-z_{0}\right) \quad$ above the canopy

$\tau_{\text {trans }}=R_{\mathrm{ac}} \cdot\left(d+z_{0}-z_{0 s}\right) \quad$ within the canopy.

The ratio between $\tau_{\text {trans }}$ and $\tau_{\text {chem }}$ is defined as the Damköhler number (DA) (Damköhler, 1940):

$\mathrm{DA}=\frac{\tau_{\text {trans }}}{\tau_{\text {chem }}}$.

According to Damköhler (1940), the divergence of a reactive trace gas flux is negligible if $\mathrm{DA} \ll 1$ (conventionally $\mathrm{DA} \leq 0.1$ ), i.e. the turbulent transport is much faster than chemical reactions, and consequently the reactive trace gas can be considered as a (quasi-)passive tracer. For DA $>0.1$ measured reactive trace gas fluxes have to be corrected for the influence of (fast) chemical reactions to obtain correct turbulent fluxes of the reactive trace gas. 


\subsection{Estimation of $\mathrm{NO}-\mathrm{O}_{3}-\mathrm{NO}_{2}$ flux divergences above the canopy}

The measured $\mathrm{NO}_{2}-\mathrm{O}_{3}-\mathrm{NO}$ fluxes were corrected for chemical reactions occurring between the canopy top and the measurement height using the method proposed by Duyzer et al. (1995)

Duyzer et al. (1995) demonstrated that the general form of the flux divergence is

$\left(\partial F_{i} / \partial z\right)_{z}=a_{i} \ln (z)+b_{i}$.

The factor $a_{i}$ is calculated for $\mathrm{NO}_{2}, \mathrm{NO}$ and $\mathrm{O}_{3}$ as

$$
\begin{aligned}
a_{\mathrm{NO}_{2}} & =-a_{\mathrm{NO}}=-a_{\mathrm{O}_{3}}=-\frac{\varphi_{X}}{k u_{*}}\left[k_{\mathrm{r}}\left(\mathrm{NO} \cdot F_{\mathrm{O}_{3}}+\mathrm{O}_{3} \cdot F_{\mathrm{NO}}\right) .\right. \\
& \left.-j_{\mathrm{NO}_{2}} \cdot F_{\mathrm{NO}_{2}}\right]
\end{aligned}
$$

where $\varphi_{X}=\varphi_{\mathrm{NO}}=\varphi_{\mathrm{O}_{3}}=\varphi_{\mathrm{NO}_{2}}=\varphi_{\mathrm{H}}$ is the stability correction function for heat (Dyer and Hicks, 1970). As shown by Lenschow and Delany (1987), the flux divergence at higher levels approaches zero. The factor $b_{i}$ was calculated for $\mathrm{NO}_{2}$, $\mathrm{NO}$ and $\mathrm{O}_{3}$ as $b_{i}=-a_{i} \ln \left(z_{\text {ref }}\right)$, assuming that at $z_{\text {ref }}=2 \mathrm{~m}$ the flux divergence was zero. For each compound, the corrected flux $\left(F_{i, \text { corr }}\right)$ is then approximated as

$$
F_{i, \text { corr }}=F_{i}+\int_{\text {zref }}^{d}\left(\frac{\partial F_{i}}{\partial z}\right)_{z} \mathrm{~d} z=F_{i}+a_{i} z_{\text {ref }}\left(1+\ln \left(\mathrm{d} / z_{\text {ref }}\right)\right) .
$$

\section{Results and discussion}

\subsection{Meteorological conditions and mixing ratios}

During the experimental period, the median value of the mean diel course of global radiation, $G_{\mathrm{r}}$, reached its maximum of $\sim 700 \mathrm{Wm}^{-2}$ at noon (Fig. 2a). The air temperature followed the same diel cycle (Fig. 2b) with median daytime maxima of $21^{\circ} \mathrm{C}$. Relative humidity, $\mathrm{RH}$, decreased during the morning to reach its minimum of $65 \%$ after noon (Fig. 2b). The meteorological conditions were different during the first half of the experiment (29 August to 9 September 2005) and the second half (10-20 September 2005). While the former period was sunny and warm and characterized by easterly flows, the latter was dominated by rainy, cold, and overcast conditions governed by westerly winds. This resulted in considerable variability of the meteorological conditions during the experiment: maximal $G_{\mathrm{r}}$ and $T_{\mathrm{a}}$ ranged between 200 and $800 \mathrm{~W} \mathrm{~m}^{-2}$, and 15 and $25^{\circ} \mathrm{C}$, respectively, and minimal RH varied between 80 and $50 \%$ (Fig. 2a and b).

Mean diel courses of $\mathrm{NO}_{2}, \mathrm{NO}$ and $\mathrm{O}_{3}$ mixing ratios measured at $1.65 \mathrm{~m}$ above ground level (profile system) are shown in Fig. 2c. Median NO mixing ratios were close to zero during the major part of the experiment and slightly increased during the morning to about $1 \mathrm{ppb}$. These elevated a
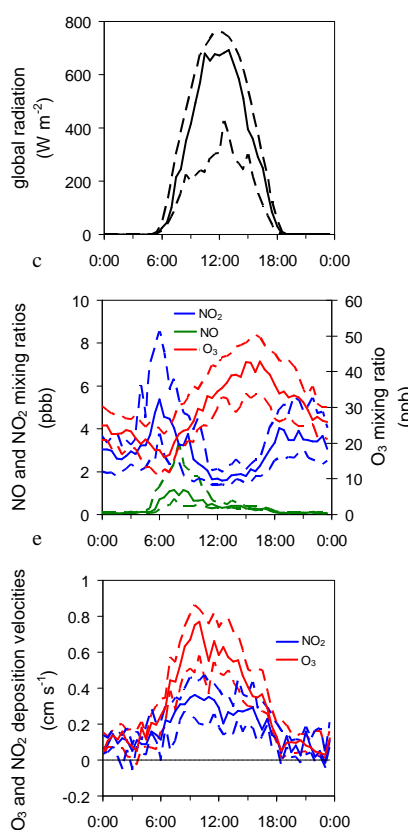

Fig. 2. Diel courses of (a) global radiation; (b) air relative humidity (blue line) and temperature (red line); (c) nitrogen dioxide (blue line), nitric oxide (green line) and ozone (red line) mixing ratios at $1.65 \mathrm{~m}$ above ground level; (d) nitrogen dioxide (blue line), nitric oxide (green line) and ozone (red line) fluxes; and (e) deposition velocities for nitrogen dioxide (blue line) and ozone (red line) determined by EC from 29 August to 20 September 2005. Solid lines represent half-hourly medians and dotted lines represent interquartile ranges. Fluxes were not corrected for chemical reactions. Only those data have been considered for which footprint analysis indicated that at least $95 \%$ of the fluxes have originated from the experimental field (see Fig. 3).

$\mathrm{NO}$ values occurred when the $\mathrm{NO}_{2}$ mixing ratio began to decrease due to photolysis. In addition, some NO was most likely advected from roads passing the site at a distance of $2 \mathrm{~km} \mathrm{NE}$ from the experimental site. Highest mixing ratios of $\mathrm{NO}_{2}$ were on average about $6 \mathrm{ppb}$ during the early morning and 4 ppb during the late afternoon, but increased occasionally up to $8 \mathrm{ppb}$. During the rest of the day, $\mathrm{NO}_{2}$ mixing ratios were around 2-3 ppb. The diel trend of $\mathrm{NO}_{2}$ was linked with photochemistry: during sunrise, $\mathrm{NO}_{2}$ photolysis led to the decrease in $\mathrm{NO}_{2}$ mixing ratios, while during nighttime the absence of photolysis and the stable stratification induced an accumulation of $\mathrm{NO}_{2}$ in the lower troposphere. $\mathrm{O}_{3}$ mixing ratios exceeded $\mathrm{NO}$ and $\mathrm{NO}_{2}$ mixing ratios and varied from 10 to $20 \mathrm{ppb}$ during nighttime and from 40 to $60 \mathrm{ppb}$ during daytime. During the morning, turbulent mixing in the planetary boundary layer led to entrainment of $\mathrm{O}_{3}$ from the free troposphere (Stull, 1989). In addition, photochemical $\mathrm{O}_{3}$ production (in the presence of $\mathrm{NO}_{\mathrm{x}}$ and volatile organic compounds) caused the increase of $\mathrm{O}_{3}$ mixing ratios during the morning, reaching its maximum in the early afternoon. The 

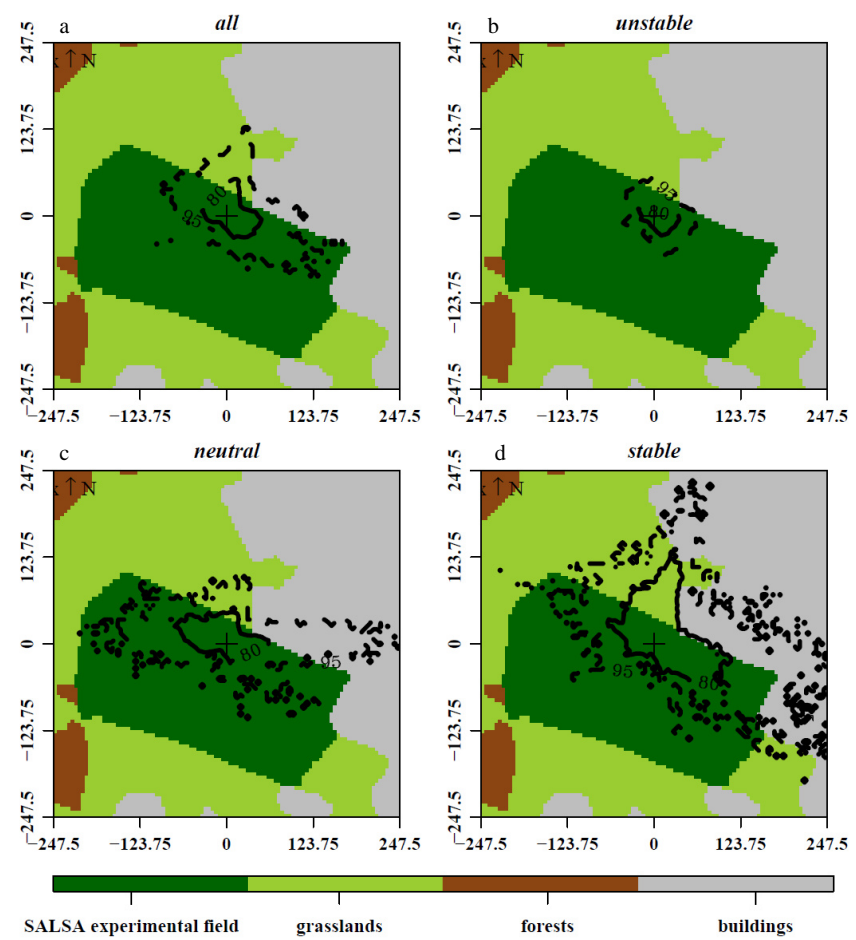

SALSA experimental field grasslands

buildings

Fig. 3. Averaged cumulative footprint contours showing the footprint areas for $80 \%$ (solid line) and $95 \%$ (dotted line) of the total flux measured by eddy covariance for (a) all, (b) unstable, (c) neutral, and (d) stable conditions. $x$ axis and $y$ axis are distances from the mast (in metre). The analysis was performed for all data from 29 August to 20 September 2005.

$\mathrm{O}_{3}$ removal by dry deposition processes and the reduced entrainment of $\mathrm{O}_{3}$ from the free troposphere as a result of thermally stable stratification and low-wind conditions induced a decrease in $\mathrm{O}_{3}$ mixing ratio during late afternoon and particularly during the night (cf. Coyle et al., 2002). Overall, $\mathrm{NO}_{2}$ and $\mathrm{O}_{3}$ mixing ratios were higher from 29 August 2005 to 9 September 2005 than from 10 to 20 September 2005.

\subsection{Footprint analysis and measured fluxes}

Since the three-pod mast, the laboratory container and some rural settlements were potentially distorting the flow in the north and in the eastern sector of our site, we performed a footprint analysis according to Göckede et al. $(2004,2006)$. Owing to the extended fetch in western, southern and southeastern directions, the major part of the fluxes measured by the EC systems originated from the experimental field, independently of the stability conditions (Fig. 3). However, the surrounding areas contributed to the total fluxes mainly in the NNW/NE sectors, due to (i) the limited fetch and (ii) the rural settlements disturbing the flow in these directions. In addition, the footprint area increased with atmospheric stability. In order to ensure that only those measured fluxes were used for subsequent analyses which orig- inated from the experimental field (and not from the surrounding areas), we considered only those $30 \mathrm{~min}$ flux data for which at least $95 \%$ of the total footprint area could be attributed to the experimental field.

$\mathrm{NO}_{2}$ and $\mathrm{O}_{3}$ fluxes were directed downward; i.e. net deposition fluxes were observed (Fig. 2d). Both $\mathrm{NO}_{2}$ and $\mathrm{O}_{3}$ deposition fluxes were close to zero during nighttime and typically increased during the morning to their maximum. Maximum deposition fluxes of $\mathrm{NO}_{2}$ occurred in the early morning and ranged on average from about $-0.3 \mathrm{nmol} \mathrm{m}^{-2} \mathrm{~s}^{-1}$ to $-0.6 \mathrm{nmol} \mathrm{m}^{-2} \mathrm{~s}^{-1}$. The deposition fluxes of $\mathrm{O}_{3}$ were about 10 to 20 times higher than $\mathrm{NO}_{2}$ fluxes, ranging on average from $-7 \mathrm{nmol} \mathrm{m}^{-2} \mathrm{~s}^{-1}$ to $-12 \mathrm{nmol} \mathrm{m}^{-2} \mathrm{~s}^{-1}$ at noon. The calculated deposition velocities for $\mathrm{NO}_{2}$ and $\mathrm{O}_{3}$ exhibited a similar diel course and increased during the morning, reaching their maximum and decreasing during the afternoon. Despite similar deposition velocities during nighttime $\left(\sim 0.1 \mathrm{~cm} \mathrm{~s}^{-1}\right)$, the maximal median deposition velocity for $\mathrm{NO}_{2}$ was two times lower than for $\mathrm{O}_{3}$ during daytime (around $0.3 \mathrm{~cm} \mathrm{~s}^{-1}$ for $\mathrm{NO}_{2}$ and $0.6 \mathrm{~cm} \mathrm{~s}^{-1}$ for $\mathrm{O}_{3}$ ) (Fig. 2e). NO fluxes measured by EC during the field experiment were close to zero during nighttime and were directed upward during daytime, i.e. indicating net emission, with maxima of $0.05-0.1 \mathrm{nmol} \mathrm{m}^{-2} \mathrm{~s}^{-1}$ during daytime (see Fig. 2d).

\subsection{Model vs. measurements: fluxes and mixing ratios}

The $\mathrm{O}_{3}$ fluxes estimated using the Surfatm model agreed well with those measured during the whole experimental period. The linear regression showed that the model underestimated the measured fluxes by only $2 \%$ on average (Fig. $4 a$ ). We attempted another step of validation of the Surfatm model by comparing measured and model-derived $\mathrm{O}_{3}$ mixing ratios at two crucial levels, namely at $z_{0}$ and $\mathrm{z}_{0 s}$. For that $\mathrm{O}_{3}$ mixing ratios were estimated (a) at $z_{0}$ from Eq. (13) using the measured $\mathrm{O}_{3}$ flux, the measured $\mathrm{O}_{3}$ mixing ratio at $z_{\text {ref }}$ and modelled $R_{\mathrm{a}}$, and (b) at $\mathrm{z}_{0 s}$ from Eq. (16) using the modelled $\mathrm{O}_{3}$ soil flux, the measured $\mathrm{O}_{3}$ mixing ratio at $20 \mathrm{~cm}$ (later moved at $28 \mathrm{~cm}$ ) and modelled $R_{\mathrm{ac}}$ values. In Fig. $4 \mathrm{~b}$ and $\mathrm{c}$ these $\mathrm{O}_{3}$ mixing ratios are shown in comparison (a) to the $\mathrm{O}_{3}$ mixing ratio measured at $20-28 \mathrm{~cm}$ assuming that $20-28 \mathrm{~cm}$ was representative of $\mathrm{z}_{0}$, and (b) to the measured $\mathrm{O}_{3}$ mixing ratio at $5 \mathrm{~cm}$ assuming that this level was representative of $\mathrm{z}_{0 s}$. At least during daytime, the modelled $\mathrm{O}_{3}$ mixing ratios just above the canopy and the soil agree very well with the measurements, which validates the applied values of $R_{\mathrm{a}}$ and $R_{\mathrm{ac}}$ (necessary to estimate transport times above and within the canopy; see Sect. 2.7). This result is indeed justified also by the fact that $\mathrm{O}_{3}$ mixing ratios modelled with $\pm 50 \%$ of $R_{\mathrm{a}}$ and $R_{\mathrm{ac}}$ (red dashed lines in Fig. $4 \mathrm{~b}, \mathrm{c})$ largely deviate from measured mixing ratios. The good agreement for $\mathrm{O}_{3}$ indicates that the resistances used to model $\mathrm{O}_{3}$ fluxes were valid and consequently represent the $\mathrm{O}_{3}$ exchange processes quite well. 

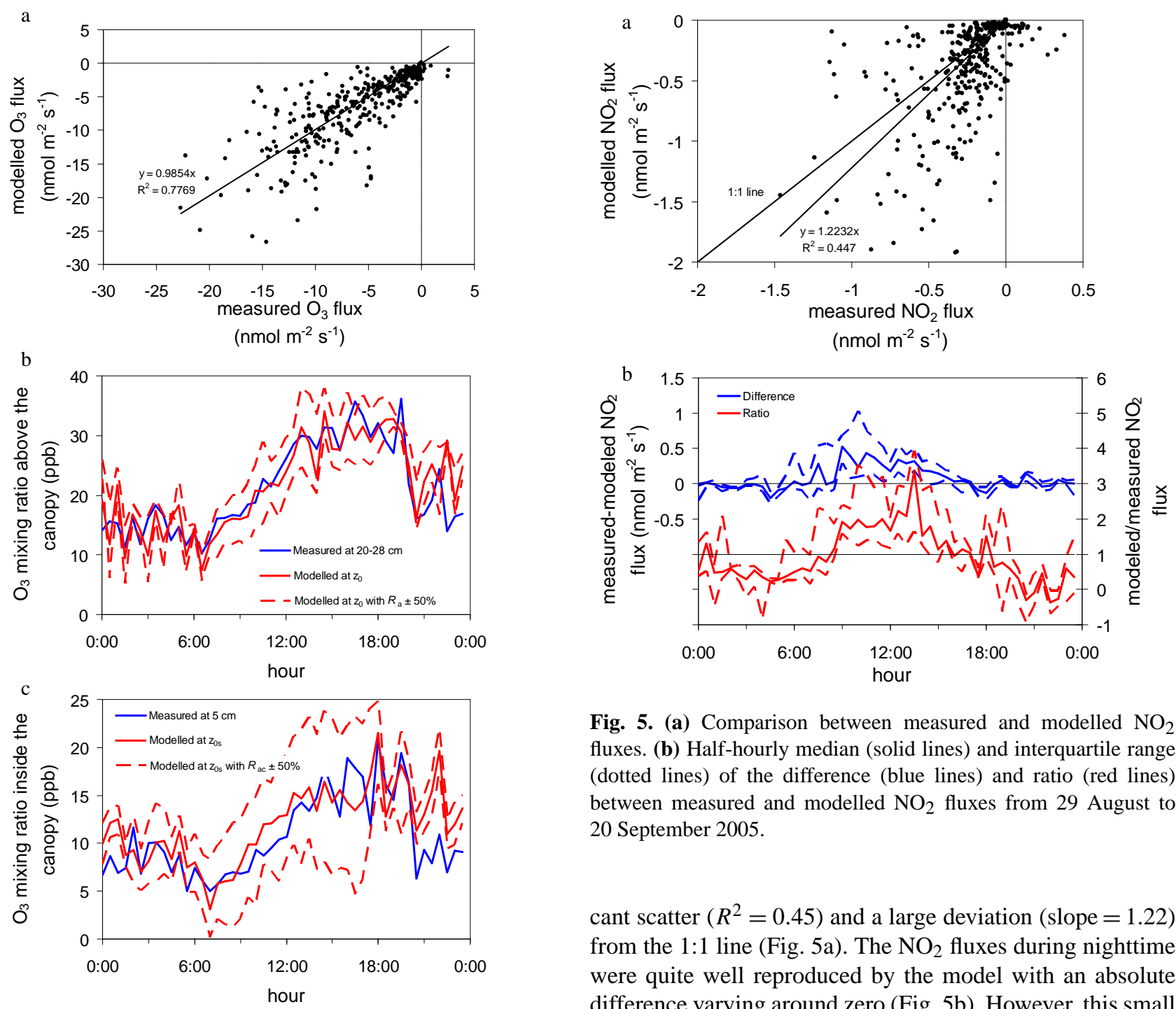

Fig. 5. (a) Comparison between measured and modelled $\mathrm{NO}_{2}$ fluxes. (b) Half-hourly median (solid lines) and interquartile range (dotted lines) of the difference (blue lines) and ratio (red lines) between measured and modelled $\mathrm{NO}_{2}$ fluxes from 29 August to 20 September 2005.

cant scatter $\left(R^{2}=0.45\right)$ and a large deviation (slope $\left.=1.22\right)$ from the 1:1 line (Fig. 5a). The $\mathrm{NO}_{2}$ fluxes during nighttime were quite well reproduced by the model with an absolute difference varying around zero (Fig. 5b). However, this small absolute difference caused a large relative difference between measured and modelled fluxes, indicating an underestimation by the model of around $50 \%$, which was due to the small $\mathrm{NO}_{2}$ fluxes during nighttime (Fig. 2d). Nevertheless, during daytime the $\mathrm{NO}_{2}$ deposition was significantly overestimated. The difference between measured and modelled $\mathrm{NO}_{2}$ fluxes increased during the morning, reached its maximum at noon and decreased during the afternoon (Fig. 5b). At noon, the modelled $\mathrm{NO}_{2}$ fluxes were typically two times larger than the measured $\mathrm{NO}_{2}$ fluxes, and this overestimation could occasionally reach a factor of three (Fig. 5b).

It is now required to understand the reasons responsible for this substantial overestimation of the a priori modelled $\mathrm{NO}_{2}$ deposition. These reasons could be separated into two categories: (i) the measured $\mathrm{NO}_{2}$ fluxes were not only caused by turbulent transport of $\mathrm{NO}_{2}$ towards the surface and/or (ii) the resistances to $\mathrm{NO}_{2}$ deposition used in the model were underestimated. On one hand, the EC method measures the flux at a specific height $\left(z_{\text {ref }}=2 \mathrm{~m}\right)$. For reactive species such as $\mathrm{NO}_{2}$, chemical reactions in the air column within or 

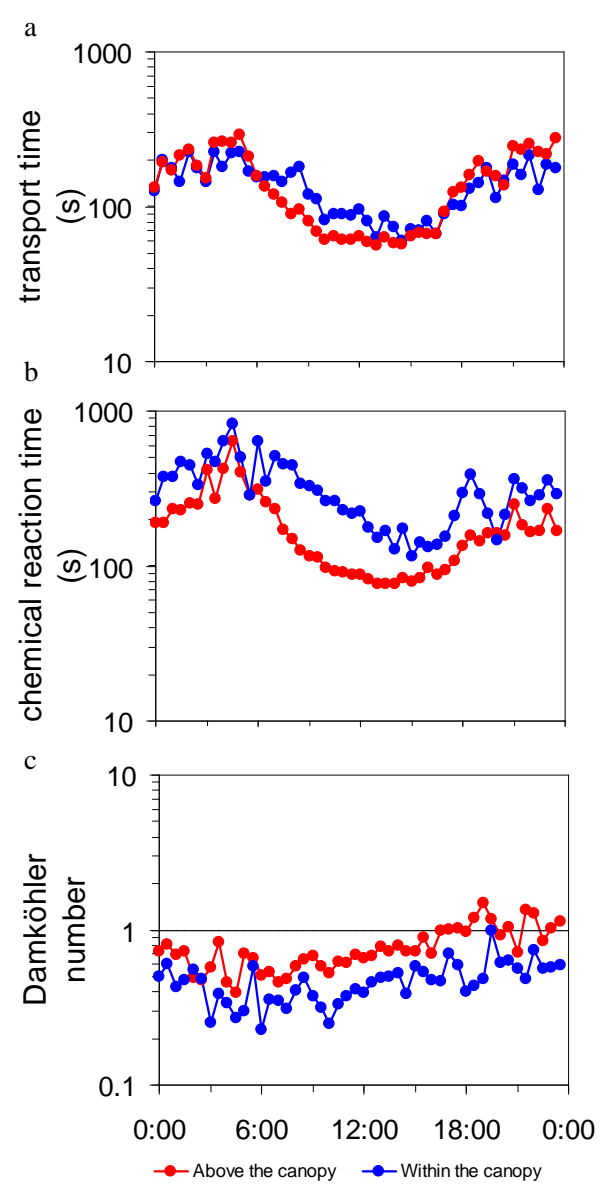

Fig. 6. Half-hourly medians of (a) transport times, (b) chemical reaction times, and (c) Damköhler numbers above (red symbols) and within (blue symbols) the canopy from 29 August to 20 September 2005 .

above the canopy could induce a flux divergence with height, meaning that the flux at the measurement height is different than the flux close to the surface, which is in contrast to inert species such as water vapour or $\mathrm{CO}_{2}$ (e.g. Kramm et al., 1991, 1996; Galmarini et al., 1997; Walton et al., 1997). If the characteristic turbulent transport times (see Eq. 20) are not significantly shorter than characteristic chemical reaction times (see Eq. 18), these processes could also induce lower deposition fluxes measured at a height of $2 \mathrm{~m}$. In addition, the EC flux measurements represent the net exchange resulting from the balance between emission and deposition processes. In case the $\mathrm{NO}_{2}$ fluxes were bi-directional, which would imply that a surface source for $\mathrm{NO}_{2}$ exists, then the deposition flux estimated by the model would be larger than the measured net flux. On the other hand, the model could also overestimate $\mathrm{NO}_{2}$ deposition, which implies that the applied resistance parameterizations in the model might be not complete. However, as explained previously, this was not the case for $R_{\mathrm{a}}, R_{\mathrm{ac}}, R_{\mathrm{bl}}, R_{\mathrm{bs}}$, and $R_{\mathrm{S}}$ since they were validated owing to the good agreement between measured and modelled
$\mathrm{O}_{3}$ fluxes. Thus, if we presume that the cuticular deposition is negligible (i.e. $R_{\mathrm{cut}}^{\mathrm{NO}_{2}}=9999 \mathrm{~s} \mathrm{~m}^{-1}$ ) as shown previously (see above), only the remaining resistances $R_{\text {soil }}$ and $R_{\text {int }}$ for $\mathrm{NO}_{2}$ could be underestimated. In the following, each reason that may explain the overestimation of $\mathrm{NO}_{2}$ deposition by the model is explored and discussed.

\subsection{Impact of chemical reactions on $\mathrm{NO}_{2}$ fluxes}

Transport and chemical reaction times for the NO- $\mathrm{O}_{3}-\mathrm{NO}_{2}$ triad were estimated above and within the canopy in order to determine to what extent chemical depletion or production in the air column could affect the measured $\mathrm{NO}_{2}$ fluxes.

Characteristic transport times $\left(\tau_{\text {trans }}\right)$ for both above and within the canopy followed a diurnal cycle (Fig. 6a). It was larger during nighttime and decreased during the morning to reach its minimum in the early afternoon. It then increased during the afternoon until sunset. Despite the difference of the layer height (above the canopy: $z_{\text {ref }}-d=1.60 \mathrm{~m}$ and $1.50 \mathrm{~m}$ at the beginning and the end of the experiment, respectively; within the canopy: $d-z_{0 s}=0.10$ and $0.19 \mathrm{~m}$ at the beginning and the end of the experiment, respectively), $\tau_{\text {trans }}$ was comparable above the canopy and within the canopy. It was about $200 \mathrm{~s}$ during nighttime and decreased to about $55 \mathrm{~s}$ above the canopy and to $80 \mathrm{~s}$ within the canopy at noon. The lower turbulence and stable atmospheric conditions during nighttime induced a slower turbulent transport, while the unstable atmospheric conditions and turbulent mixing enhancement reduced $\tau_{\text {trans }}$. Although $\tau_{\text {trans }}$ was comparable above and within the canopy, it must be kept in mind that the layer height was different, being $1.50 \mathrm{~m}$ above and only $0.20 \mathrm{~m}$ within the canopy. This implies that the "transfer velocity" was significantly lower within the canopy than above.

Characteristic chemical reaction times were calculated above and within the canopy. Above the canopy, $\tau_{\text {chem }}$ was calculated using Eq. (18), i.e. taking into account both $\mathrm{NO}_{2}$ photolysis and $\mathrm{NO}_{2}$ production by the reaction between $\mathrm{O}_{3}$ and NO. However, $j_{\mathrm{NO} 2}$ was not measured inside the canopy; hence, $\tau_{\text {chem }}$ could not be calculated using Eq. (18). Since $j_{\mathrm{NO}_{2}}$ is closely related to $G_{\mathrm{r}}$ (see Trebs et al., 2009), which typically sharply decreases in a dense canopy, $\mathrm{NO}_{2}$ photolysis was assumed to be negligible. In addition, the measured $\mathrm{O}_{3}$ mixing ratio at $0.05 \mathrm{~m}$ above ground level was about 10 times larger than the measured NO mixing ratio in the early morning and up to 30 times larger during the afternoon and nighttime (data not shown). The reaction between NO and $\mathrm{O}_{3}$ is a second-order reaction, but can be approximated by a pseudo-first-order reaction because $\mathrm{O}_{3}$ was in excess compared to NO. The pseudo-first-order reaction rate constant is defined as $k_{\mathrm{r}}^{\prime}=k_{\mathrm{r}} \times O_{3}\left(\right.$ in s $\left.^{-1}\right)$, and $\tau_{\text {chem }}$ inside the canopy can be approximated as the chemical depletion time for NO (Eq. 19a). The chemical reaction time followed the same diurnal cycle above and within the canopy: it reached its maximum in the early morning, progressively decreased to reach a 

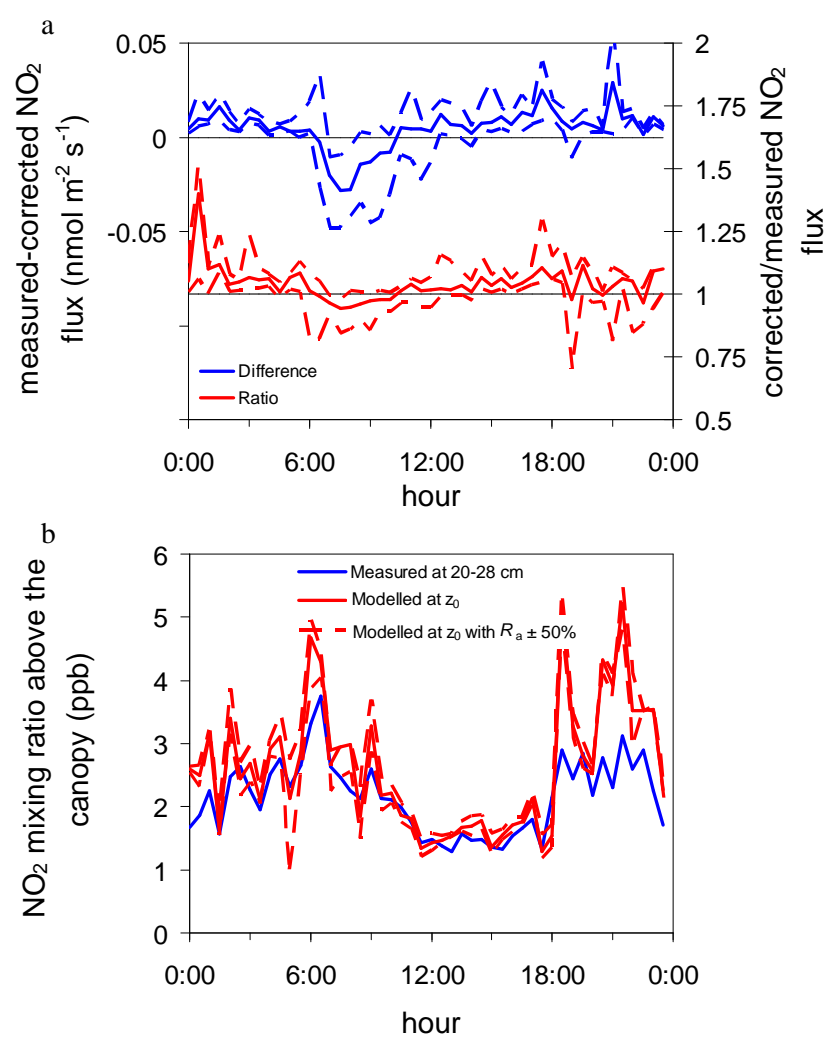

Fig. 7. (a) Half-hourly median (solid line) and interquartile range (dotted lines) of the difference (blue lines) and the ratio (red lines) between measured $\mathrm{NO}_{2}$ fluxes at $z=2.0 \mathrm{~m}$ and $\mathrm{NO}_{2}$ fluxes corrected for chemical reactions above the canopy from 29 August to 20 September 2005. (b) Comparison between measured (blue line) and modelled (red lines) $\mathrm{NO}_{2}$ mixing ratio above the canopy. Dotted lines are mixing ratios modelled with an uncertainty of $\pm 50 \%$ for the aerodynamic resistance. For details see text.

minimum in early afternoon, and increased from the early afternoon to the early morning (Fig. 6b). In spite of the comparable diurnal cycle above and within the canopy, $\tau_{\text {chem }}$ above the canopy was usually faster than inside the canopy. The chemical reaction time above the canopy peaked at $300 \mathrm{~s}$ and decreased to $80 \mathrm{~s}$, whereas inside the canopy it reached $600 \mathrm{~s}$ and decreased to only $150 \mathrm{~s}$ (Fig. 6b).

The DA values calculated from Eq. (21) were usually lower than unity, implying that in general turbulent transport was faster than chemical reactions, although DA was occasionally close to unity (Fig. 6c). In addition, DA was larger above the canopy than within the canopy due to the faster chemical reaction time above the canopy. DA values varied between 0.3 and 0.7 within the canopy and ranged from 0.5 to unity above the canopy. Damköhler (1940) stated that a trace gas can be treated as a non-reactive tracer for $\mathrm{DA} \ll 1$. However, it is now generally accepted by the scientific community that a gas can be treated as non-reactive only for $\mathrm{DA}<0.1$, and that chemical divergence could be of minor importance for $0.1<\mathrm{DA}<1$. For example, Stella et al. (2012) demon- strated that chemical reactions induced a flux divergence for $\mathrm{O}_{3}$ and $\mathrm{NO}$ accounting for $0-25 \%$ of the measured fluxes for $0.1<\mathrm{DA}<1$.

Consequently, the impact of chemical reactions for the $\mathrm{NO}-\mathrm{O}_{3}-\mathrm{NO}_{2}$ triad above the canopy on measured $\mathrm{NO}_{2}$ fluxes was evaluated using the method proposed by Duyzer et al. (1995). According to this method, chemistry between $\mathrm{NO}, \mathrm{NO}_{2}$ and $\mathrm{O}_{3}$ above the canopy could induce only a small divergence. The median difference between the measured and the corrected $\mathrm{NO}_{2}$ fluxes varied between $\pm 0.025 \mathrm{nmol} \mathrm{m}^{-2} \mathrm{~s}^{-1}$, which corresponded to a relative difference of $\pm 10 \%$ (Fig. 7a), whereas the difference between measured and modelled $\mathrm{NO}_{2}$ fluxes was about 20 times larger (absolute difference $\approx 0.40 \mathrm{nmol} \mathrm{m}^{-2} \mathrm{~s}^{-1}$, ratio $\approx 2$ during daytime; see Fig. $5 \mathrm{~b}$ and Sect. 3.3). Hence, chemistry above the canopy did not explain the large overestimation of $\mathrm{NO}_{2}$ deposition fluxes by the model. In addition, similarly to $\mathrm{O}_{3}$, the $\mathrm{NO}_{2}$ mixing ratio was estimated at $z_{0}$ from Eq. (13) using the measured $\mathrm{NO}_{2}$ flux, the measured $\mathrm{NO}_{2}$ mixing ratio at $z_{\text {ref }}$ and modelled $R_{\mathrm{a}}$, and compared with the $\mathrm{NO}_{2}$ mixing ratio estimated at $20-28 \mathrm{~cm}$ (Fig. $7 \mathrm{~b}$ ). Since the resistance analogy implies the absence of chemical reactions, the good agreement between measured and modelled $\mathrm{NO}_{2}$ mixing ratio above the canopy also confirmed the non-significance of chemistry above the canopy, at least during daytime. Nevertheless, during nighttime, discrepancies occurred between measured and modelled $\mathrm{NO}_{2}$ mixing ratios, meaning that fast chemistry cannot be discarded

These methods could not be used to estimate the influence of chemical reactions inside the canopy since (i) the method proposed by Duyzer et al. (1995) is based on mass conservation of the $\mathrm{NO}-\mathrm{O}_{3}-\mathrm{NO}_{2}$ triad and it does not integrate the different emission or deposition processes that could occur inside the canopy, and (ii) the comparison of measured and modelled $\mathrm{NO}_{2}$ mixing ratios inside the canopy (i.e. at $5 \mathrm{~cm}$ ) requires knowledge of the modelled soil $\mathrm{NO}_{2}$ flux, or at least the vegetation flux (to deduce the soil flux from the difference between total and vegetation $\mathrm{NO}_{2}$ flux), which cannot be estimated without knowledge of the $\mathrm{NO}_{2}$ internal resistance. However, our results suggest that the impact of $\mathrm{NO}-\mathrm{O}_{3}-\mathrm{NO}_{2}$ chemistry inside the canopy could be negligible. The calculated DA numbers did not indicate that chemistry was dominating the exchange inside the canopy. In addition, the DA number inside the canopy was lower than above the canopy (Fig. 6c), which implies that chemistry inside the canopy was probably even less important than above the canopy.

It also has to be mentioned that besides $\mathrm{NO}-\mathrm{O}_{3}-\mathrm{NO}_{2}$ chemistry, other reactions could induce chemical divergence, especially those involving biogenic volatile organic compounds (BVOCs). BVOCs are emitted from vegetation (Guenther et al., 2000; Karl et al., 2001; Beauchamp et al., 2005; Goldstein and Galbally, 2007), including a large variety of compounds (e.g. isoprene, monoterpenes, sesquiterpenes, acetone, methanol, ethanol) with highly variable reactivity (Atkinson and Arey, 2003; Bamberger et al., 2010; 


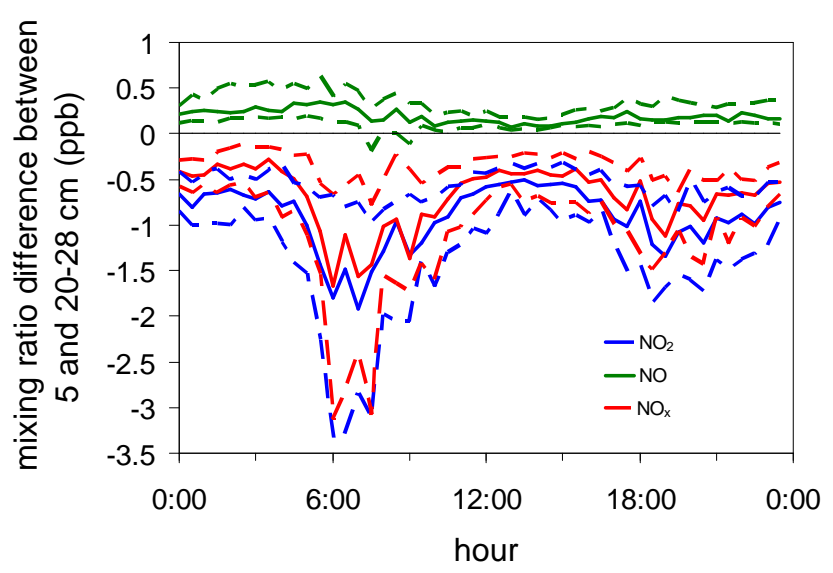

Fig. 8. Mean diurnal cycle of in-canopy mixing ratio differences for $\mathrm{NO}, \mathrm{NO}_{2}$, and $\mathrm{O}_{3}$ between $5 \mathrm{~cm}$ and $20-28 \mathrm{~cm}$ (increasing canopy top) above ground. Solid lines show median values and dashed lines the interquartile range, respectively, for the entire measurement period.

Ruuskanen et al., 2011). As indicated in Atkinson and Arey (2003), the lifetime of BVOCs for the reaction with $\mathrm{O}_{3}$ ranges from few minutes (e.g. $\alpha$-Terpinene, $\alpha$-Humulene, $\beta$ Caryophyllene) to several hours/months (e.g. isoprene, acetone, methanol). Bamberger et al. (2010) reported that only methanol exhibited consistent fluxes above a grassland. Since the lifetime of methanol for reaction with $\mathrm{O}_{3}$ is very long (> $4.5 \mathrm{yr}$; Atkinson and Arey, 2003), we expect a negligible impact of BVOC chemistry on $\mathrm{NO}, \mathrm{O}_{3}$ and $\mathrm{NO}_{2}$. This hypothesis is also supported by the good agreement between measured and modelled $\mathrm{NO}_{2}$ mixing ratio above the canopy (Fig. 7b).

\subsection{Near-soil $\mathrm{NO}_{2}$ source and compensation point for $\mathrm{NO}_{2}$}

In the following we discuss the possibility of the existence of a significant $\mathrm{NO}_{2}$ source near the soil surface that would cause a difference between the observed above-canopy $\mathrm{NO}_{2}$ flux and the total $\mathrm{NO}_{2}$ deposition. It would imply the existence of a non-zero canopy or soil compensation point in the resistance model.

The potential reason for an $\mathrm{NO}_{2}$ source is a soil $\mathrm{NO}$ emission that is higher than the NO eddy covariance flux observed above the canopy (Fig. 2). There are no direct in situ measurements of soil NO emissions available in the present study, but we estimated the soil emission potential by laboratory incubation measurements (Sect. 2.5). For the period of the field experiment, the laboratory-derived soil NO flux ranged from 0.08 to $0.35 \mathrm{nmol} \mathrm{m}^{-2} \mathrm{~s}^{-1}$ (median: $\left.0.2 \mathrm{nmol} \mathrm{m}^{-2} \mathrm{~s}^{-1}\right)$. The values are on average higher than the corresponding above-canopy flux, and a large part of it may have been converted to $\mathrm{NO}_{2}$ already in the lower part of the canopy (see Mayer et al., 2011; Foken et al., 2012b).

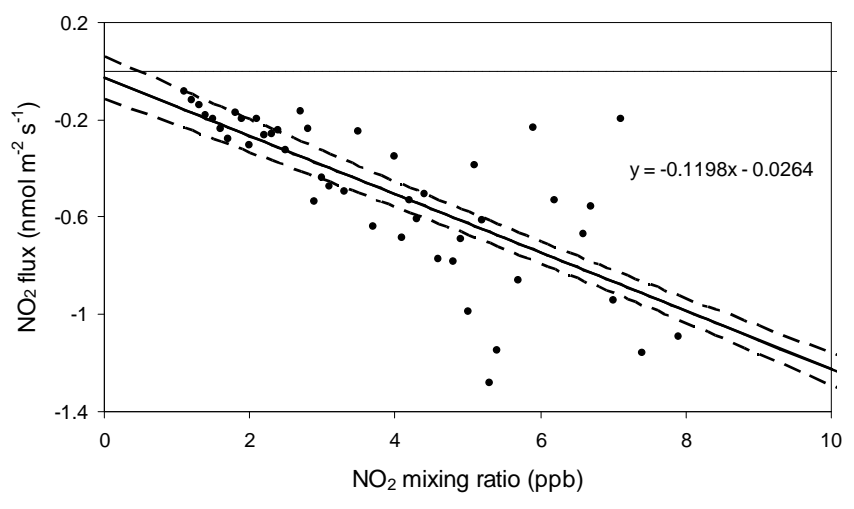

Fig. 9. Measured $\mathrm{NO}_{2}$ flux as a function of the $\mathrm{NO}_{2}$ mixing ratio $(z=2.0 \mathrm{~m})$ from 29 August to 20 September 2005. Solid and dotted lines are the regression line and its $95 \%$ confidence interval, respectively. $\mathrm{NO}_{2}$ fluxes were corrected for chemical reactions above the canopy and averaged for $\mathrm{NO}_{2}$ mixing ratio bins of $0.1 \mathrm{ppb}$. Only data for $G_{\mathrm{r}}>400 \mathrm{~W} \mathrm{~m}^{-2}$ were included.

However, it has to be considered that the laboratory measurements have been performed with sieved soil. The absence of the usually dense active grass roots (as a competitive sink for mineral nitrogen) may have enhanced the soil microbial processes and led to an overestimation of NO emission compared to an intact plant-soil system, similarly to the effect of grassland tillage (see e.g. Pinto et al., 2004). Another argument against a significant $\mathrm{NO}_{2}$ source in the lower canopy is the observed in-canopy gradients between $5 \mathrm{~cm}$ and $20-$ $28 \mathrm{~cm}$. As shown in Fig. 8, the $\mathrm{NO}_{2}$ concentration always increased with height, indicating a general downward flux inside the canopy. This is even true for the chemically conserved $\mathrm{NO}_{\mathrm{x}}$ concentration, indicating that the soil and the air layer above $(0-5 \mathrm{~cm})$ were generally a net sink for $\mathrm{NO}_{\mathrm{x}}$. It cannot be discarded that chemical conversion occurs just above or in contact to the soil surface, but it obviously does not significantly affect the present analysis.

In addition to these findings, the existence of a canopy compensation point (the $\mathrm{NO}_{2}$ mixing ratio just above the vegetation elements at which consumption and production processes balance each other) was empirically explored. Figure 9 shows the measured $\mathrm{NO}_{2}$ fluxes corrected for chemical reactions above the canopy versus the measured $\mathrm{NO}_{2}$ mixing ratios. Only data for $G_{\mathrm{r}}>400 \mathrm{~W} \mathrm{~m}^{-2}$ were considered, a threshold above which stomatal conductance is supposed to be constant. The linear regression between the $\mathrm{NO}_{2}$ flux and the $\mathrm{NO}_{2}$ mixing ratio did not show an intersection of the regression line with the $x$ axis $\left(\mathrm{NO}_{2}\right.$ mixing ratio) within the error of the regression at the $95 \%$ confidence interval. Hence, these results do not suggest the existence of a canopy compensation point, and thus indicate the non-existence of an $\mathrm{NO}_{2}$ emission flux at the meadow. In addition, this result also supports the small influence of chemical $\mathrm{NO}_{2}$ production inside the canopy, as stated previously. 


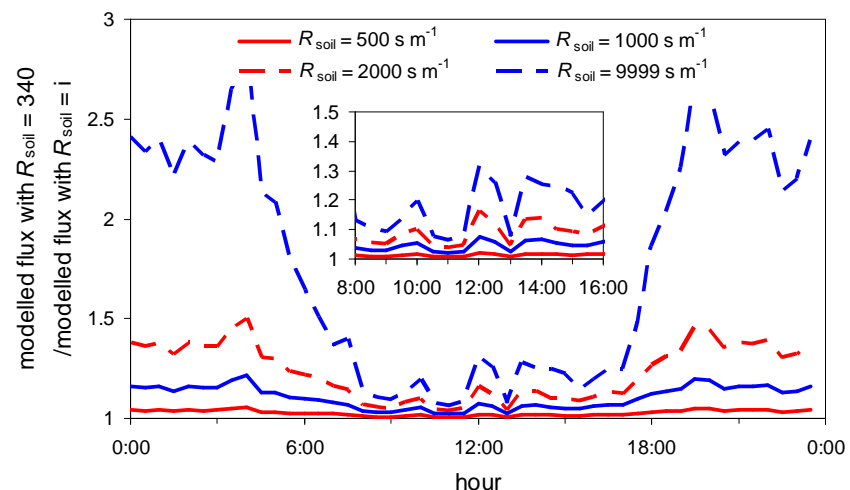

Fig. 10. Half-hourly median of the response of the modelled $\mathrm{NO}_{2}$ deposition flux to the soil resistance for $R_{\text {soil }}^{\mathrm{NO}_{2}}=500 \mathrm{~s} \mathrm{~m}^{-1}$ (solid red line), $R_{\text {soil }}^{\mathrm{NO}_{2}}=1000 \mathrm{~s} \mathrm{~m}^{-1}$ (solid blue line), $R_{\text {soil }}^{\mathrm{NO}_{2}}=$ $2000 \mathrm{~s} \mathrm{~m}^{-1}$ (dotted red line), and $R_{\text {soil }}^{\mathrm{NO}_{2}}=9999 \mathrm{~s} \mathrm{~m}^{-1}$ (dotted blue line) from 29 August to 20 September 2005. The reference $\mathrm{NO}_{2}$ flux was modelled using $R_{\mathrm{soil}}^{\mathrm{NO}_{2}}=340 \mathrm{~s} \mathrm{~m}^{-1}$.

The existence of the $\mathrm{NO}_{2}$ compensation point, as well as its magnitude, is currently subject to debate (Lerdau et al., 2000). Numerous studies carried out over several ecosystems such as forests, croplands and grasslands reported $\mathrm{NO}_{2}$ compensation points on the leaf or branch level ranging from less than 0.1 to $1.5 \mathrm{ppb}$ (Johansson, 1987; Weber and Rennenberg, 1996; Gebler et al., 2000, 2002; Hereid and Monson, 2001; Teklemariam and Sparks, 2006). However, these studies used (i) non-specific $\mathrm{NO}_{2}$ detection techniques using molybdenum or iron sulphate converters and (ii) chamber methods to measure the exchange of $\mathrm{NO}_{2}$ at the leaf level. These methods could lead to an overestimation of the $\mathrm{NO}_{2}$ compensation point estimation due to (i) overestimation of the $\mathrm{NO}_{2}$ mixing ratio (Parrish and Fehsenfeld, 2000; Dunlea et al., 2007; Dari-Salisburgo et al., 2009) and (ii) underestimation of the $\mathrm{NO}_{2}$ deposition flux due to chemistry inside the chambers as discussed by Meixner et al. (1997), Pape et al. (2009), Chaparro-Suarez (2011) and Breuninger et al. (2012). Our results underline the findings of Gut et al. (2002) on Amazonian forest trees and by Segschneider et al. (1995) on sunflower. In addition, Chaparro-Suarez et al. (2011) and Breuninger et al. (2012), who made measurements on pine, birch, beech and oak using a specific $\mathrm{NO}_{2}$ converter (see Sect. 2.3) and performed corrections for chemical reactions inside the chamber, did not find a compensation point for $\mathrm{NO}_{2}$.

\subsection{Model sensitivity to soil resistance for $\mathrm{NO}_{2}$}

A sensitivity analysis of the Surfatm model to $R_{\text {soil }}^{\mathrm{NO}_{2}}$ was made in order to evaluate to what extent a potential underestimation of the $\mathrm{NO}_{2}$ soil resistance could explain the overestimation of the a priori modelled $\mathrm{NO}_{2}$ deposition fluxes. The $\mathrm{NO}_{2}$ deposition flux was modelled using four differ- ent soil resistances $\left(R_{\mathrm{soil}}^{\mathrm{NO}_{2}}=500 \mathrm{~s} \mathrm{~m}^{-1}, R_{\mathrm{soil}}^{\mathrm{NO}_{2}}=1000 \mathrm{~s} \mathrm{~m}^{-1}\right.$, $R_{\text {soil }}^{\mathrm{NO}_{2}}=2000 \mathrm{~s} \mathrm{~m}^{-1}$, and $\left.R_{\text {soil }}^{\mathrm{NO}_{2}}=9999 \mathrm{~s} \mathrm{~m}^{-1}\right)$ and compared to the reference case (i.e. $R_{\text {soil }}^{\mathrm{NO}_{2}}=340 \mathrm{~s} \mathrm{~m}^{-1}$ ).

The modelled $\mathrm{NO}_{2}$ deposition decreased when $R_{\text {soil }}^{\mathrm{NO}_{2}}$ increased (Fig. 10). However, the sensitivity of the model result to $R_{\text {soil }}^{\mathrm{NO}_{2}}$ was dependent on the time of the day. The relative decrease of the modelled $\mathrm{NO}_{2}$ deposition flux with increasing $R_{\text {soil }}^{\mathrm{NO}_{2}}$ was less marked during daytime than during nighttime. It was around $1.5,4,8.5$, and $16 \%$ during daytime for $R_{\text {soil }}^{\mathrm{NO}_{2}}$ equal to 500, 1000, 2000, and $9999 \mathrm{~s} \mathrm{~m}^{-1}$, respectively, whereas during nighttime the increase of $R_{\text {soil }}^{\mathrm{NO}_{2}}$ caused a decrease of the modelled $\mathrm{NO}_{2}$ deposition flux of around 4, 13, 25, and $240 \%$ for the four cases considered (Fig. 10).

This diurnal variation was due to the change of the $\mathrm{NO}_{2}$ deposition pathways during the course of the day. During daytime, $\mathrm{NO}_{2}$ is deposited through stomatal and soil pathways, the former representing the main $\mathrm{NO}_{2}$ removal pathway (Rondón et al., 1993; Gut et al., 2002). Since $\mathrm{NO}_{2}$ soil deposition represents only a small part of the total deposition, any increase of $R_{\text {soil }}^{\mathrm{NO}_{2}}$ does not induce a large modification of the modelled $\mathrm{NO}_{2}$ deposition flux. Conversely, the soil pathway represents the only sink for $\mathrm{NO}_{2}$ during nighttime. Thus, the sensitivity of the modelled $\mathrm{NO}_{2}$ flux to $R_{\text {soil }}^{\mathrm{NO}_{2}}$ is larger.

Obviously, a potential underestimation of $R_{\text {soil }}^{\mathrm{NO}_{2}}$ did not explain the observed discrepancy between measured and modelled $\mathrm{NO}_{2}$ fluxes. For realistic values of $R_{\mathrm{soil}}^{\mathrm{NO}_{2}}\left(500 \mathrm{~s} \mathrm{~m}^{-1}\right.$ and $1000 \mathrm{~s} \mathrm{~m}^{-1}$ ) the modelled $\mathrm{NO}_{2}$ fluxes were only less than $5 \%$ lower during daytime than the fluxes modelled with $R_{\text {soil }}^{\mathrm{NO}_{2}}=340 \mathrm{~s} \mathrm{~m}^{-1}$, whereas the model overestimated measurements by about a factor of two (Fig. 5b). Even if we assume that the soil deposition was zero (i.e. $R_{\text {soil }}^{\mathrm{NO}_{2}}=9999 \mathrm{~s} \mathrm{~m}^{-1}$ ), that would only explain a model overestimation of $13 \%$.

Consequently, neither an underestimation of $R_{\text {soil }}^{\mathrm{NO}_{2}}$ nor chemical divergence within and above the canopy or $\mathrm{NO}_{2}$ emission from vegetation explained the large overestimation of the $\mathrm{NO}_{2}$ deposition fluxes by the model during daytime. In addition, $R_{\mathrm{a}}, R_{\mathrm{ac}}, R_{\mathrm{bl}}, R_{\mathrm{bs}}$, and $R_{\mathrm{s}}$ were already validated owing to the good agreement between measured and modelled $\mathrm{O}_{3}$ fluxes (see Sect. 3.3). These facts prove that the only process that could explain the overestimation of the modelled $\mathrm{NO}_{2}$ deposition flux is the existence of an internal resistance for $\mathrm{NO}_{2}$, which was ignored in the modelling approach.

\subsection{Internal resistance for $\mathrm{NO}_{2}$}

In the a priori model parameterization presented above the internal resistance for $\mathrm{NO}_{2}$ was set to zero. According to the pervious results, only the existence of a significant internal resistance could explain the large discrepancy between measured and modelled $\mathrm{NO}_{2}$ fluxes. In order to estimate the magnitude of $R_{\mathrm{int}}^{\mathrm{NO}_{2}}, \mathrm{NO}_{2}$ fluxes were modelled including several values of $R_{\text {int }}^{\mathrm{NO}_{2}}$ (i.e. $50-500 \mathrm{~s} \mathrm{~m}^{-1}$, with 
Table 2. Comparison of measured and modelled $\mathrm{NO}_{2}$ fluxes for different values of the internal resistance. Only data for $1 / R_{\mathrm{S}} \mathrm{NO}_{2}>0.2 \mathrm{~cm} \mathrm{~s}{ }^{-1}$ $\left(R_{\mathrm{S}}^{\mathrm{NO}_{2}}<500 \mathrm{~s} \mathrm{~m}^{-1}\right)$ were included.

\begin{tabular}{lcccccccccc}
\hline $\begin{array}{l}R_{\text {int }}^{\mathrm{NO}_{2}} \\
\left(\mathrm{~s} \mathrm{~m}^{-1}\right)\end{array}$ & 50 & 100 & 150 & 200 & 250 & 300 & 350 & 400 & 450 & 500 \\
\hline $\begin{array}{l}\text { Slope of the } \\
\text { regression }\end{array}$ & 1.19 & 0.94 & 0.79 & 0.70 & 0.63 & 0.57 & 0.53 & 0.50 & 0.47 & 0.44 \\
\hline $\begin{array}{l}\text { RMSE } \\
\left(\mathrm{nmol} \mathrm{m}^{-2} \mathrm{~s}^{-1}\right)\end{array}$ & 0.33 & 0.23 & 0.21 & 0.22 & 0.23 & 0.25 & 0.26 & 0.27 & 0.28 & 0.29 \\
\hline
\end{tabular}

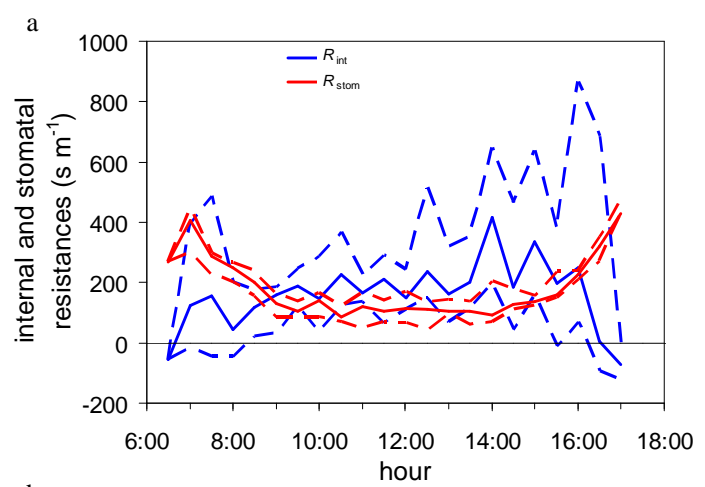

b

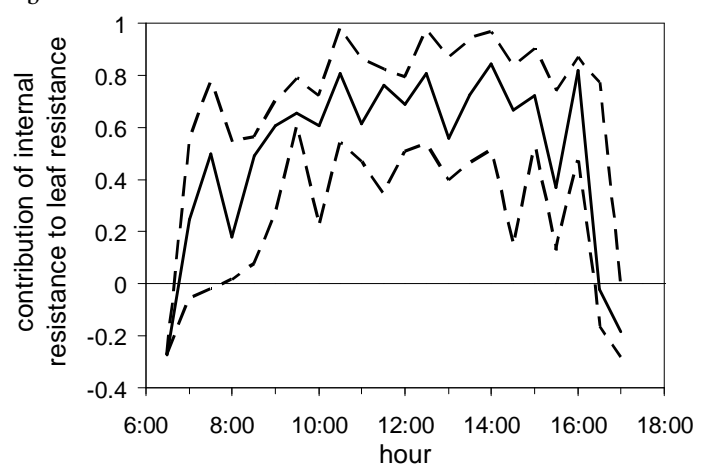

Fig. 11. Half-hourly medians (solid lines) and interquartile range (dotted lines) of (a) $\mathrm{NO}_{2}$ internal (blue lines) and stomatal resistances (red lines) and (b) the relative contribution of internal resistance to the total leaf resistance (i.e. $R_{\mathrm{int}}^{\mathrm{NO}_{2}} /\left(\frac{1}{R_{\text {cut }} \mathrm{NO}_{2}}+\frac{1}{R_{\mathrm{int}}^{\mathrm{NO}_{2}}+R_{s}^{\mathrm{NO}_{2}}}\right)^{-1}$ ) during daytime from $29 \mathrm{Au}-$ gust to 20 September 2005. Only data for $1 / R_{S}^{\mathrm{NO}_{2}}>0.2 \mathrm{~cm} \mathrm{~s}^{-1}$ $\left(R_{S}^{\mathrm{NO}_{2}}<500 \mathrm{~s} \mathrm{~m}^{-1}\right)$ were included.

steps of $50 \mathrm{~s} \mathrm{~m}^{-1}$ ). The results are summarized in Table 2 . Following this analysis, it is not clear what was the best value for $R_{\mathrm{int}}^{\mathrm{NO}_{2}}$. The best slope of the regression (0.94) was found for $R_{\mathrm{int}}^{\mathrm{NO}_{2}}=100 \mathrm{~s} \mathrm{~m}^{-1}$, but the lowest RMSE $\left(0.21 \mathrm{nmol} \mathrm{m}^{-2} \mathrm{~s}^{-1}\right)$ was found for a value of $R_{\mathrm{int}}^{\mathrm{NO}_{2}}=150 \mathrm{~s}$ $\mathrm{m}^{-1}$. Hence, we also deduced $R_{\mathrm{int}}^{\mathrm{NO}_{2}}$ in an alternative empirical approach from the $\mathrm{NO}_{2}$ flux measurements by invert- ing the resistive scheme (leaving all other resistances as described above for the a priori approach). For large $R_{s}^{\mathrm{NO}_{2}}$ values that have a high relative uncertainty, this calculation procedure may lead to errors and sometimes even to negative values of $R_{\mathrm{int}}^{\mathrm{NO}_{2}}$. Hence, only data for $1 / R_{\mathrm{S}}^{\mathrm{NO}_{2}}>0.2 \mathrm{~cm} \mathrm{~s}^{-1}$ $\left(R_{\mathrm{S}}^{\mathrm{NO}_{2}}<500 \mathrm{~s} \mathrm{~m}^{-1}\right)$ were considered.

The magnitude of $R_{\mathrm{int}}^{\mathrm{NO}_{2}}$ was highly variable throughout the day (Fig. 11a). It was close to zero during the early morning and progressively increased to $200 \mathrm{~s} \mathrm{~m}^{-1}$ at noon. The maximal median of $R_{\mathrm{int}}^{\mathrm{NO}_{2}}$ was prevailing during the early afternoon and was about $300 \mathrm{~s} \mathrm{~m}^{-1}$. The averaged $R_{\mathrm{int}}^{\mathrm{NO}_{2}}$ was $165 \mathrm{~s} \mathrm{~m}^{-1}$, but the magnitude of the estimated $R_{\mathrm{int}}^{\mathrm{NO}_{2}}$ varied considerably and ranged from 100 to $800 \mathrm{~s} \mathrm{~m}^{-1}$ (interquartile range). In comparison, $R_{\mathrm{S}}^{\mathrm{NO}_{2}}$ was around $400 \mathrm{~s} \mathrm{~m}^{-1}$ during the early morning and progressively decreased to $100 \mathrm{~s} \mathrm{~m}^{-1}$. It then increased again during the early afternoon (Fig. 11a). The contribution of $R_{\mathrm{int}}^{\mathrm{NO}_{2}}$ to the total leaf resistance varied during the day. The contribution was close to zero during the early morning but increased to represent between 50 and $90 \%$ (interquartile range), with the median contribution of $R_{\mathrm{int}}^{\mathrm{NO}_{2}}$ to the total leaf resistance estimated to be $75 \%$ during the early afternoon (Fig. 11b).

Contrary to the results obtained by Segschneider et al. (1995) for sunflower and Geßler et al. $(2000,2002)$ for beech and spruce, we found the existence of an internal leaf resistance for $\mathrm{NO}_{2}$. The results obtained during this study confirmed those obtained by Jonhansson (1987) and Gut et al. (2002), who reported significant values of $R_{\text {int }}^{\mathrm{NO}_{2}}$ ranging from 10 to $2000 \mathrm{~s} \mathrm{~m}^{-1}$. As reported in these previous studies $R_{\mathrm{int}}^{\mathrm{NO}_{2}}$ contributed significantly to the total leaf resistance. Nevertheless, its contribution was slightly larger than reported by Jonhansson (1987), who indicated that $R_{\text {int }}^{\mathrm{NO}_{2}}$ represented between 3 and $60 \%$ of the total leaf resistance, and by Gut et al. (2002) and Chaparro-Suarez (2011), who both estimated that $R_{\text {int }}^{\mathrm{NO}_{2}}$ accounted for $40 \%$ of the total leaf resistance.

Both $R_{\text {int }}^{\mathrm{NO}_{2}}$ and its contribution to the total leaf resistance exhibited a diurnal cycle: they increased during the morning but did not decrease in the same proportion during the afternoon. The underlying processes responsible for $R_{\mathrm{int}}^{\mathrm{NO}_{2}}$ 
are the reactions involving $\mathrm{NO}_{2}$ with apoplastic ascorbate and nitrate reductase (Eller and Sparks, 2006; Teklemarian and Sparks, 2006; Hu and Sun, 2010). The higher the concentrations of ascorbate and nitrate reductase are, the higher is the depletion of $\mathrm{NO}_{2}$ in the sub-stomatal cavity and the lower is $R_{\mathrm{int}}^{\mathrm{NO}_{2}}$. However, these reactions are irreversible, and ascorbate and nitrate reductase are not immediately regenerated. Thus, the dynamics of $R_{\mathrm{int}}^{\mathrm{NO}_{2}}$ and its contribution to the total leaf resistance probably reflect these biological processes: the pool of apoplastic ascorbate and nitrate reductase progressively decreased during the morning due to the reactions with $\mathrm{NO}_{2}$, leading to the increase of $R_{\mathrm{int}}^{\mathrm{NO}_{2}}$ in the afternoon. Since these substances are not regenerated immediately, $R_{\mathrm{int}}^{\mathrm{NO}_{2}}$ remained at its maximum value during the afternoon. Finally, during nighttime when stomatal closure prevented $\mathrm{NO}_{2}$ from entering into the sub-stomatal cavity (and thus did not react with apoplastic ascorbate and nitrate reductase), the pool of ascorbate and nitrate reductase was regenerated leading to minimum $R_{\mathrm{int}}^{\mathrm{NO}_{2}}$ values in the morning.

\section{Conclusions}

This study reports about measurements of $\mathrm{NO}, \mathrm{NO}_{2}$ and $\mathrm{O}_{3}$ exchanges between a meadow and the atmosphere using eddy covariance, a method without disturbance of the micrometeorological conditions and without impacts on plant functioning.

Initially, our a priori $\mathrm{NO}_{2}$ deposition fluxes modelled with the Surfatm model did not consider any internal resistance. In this case, the modelled $\mathrm{NO}_{2}$ deposition flux exceeded the measured $\mathrm{NO}_{2}$ deposition flux by a factor of two. In order to identify the processes responsible for this overestimation, (i) the influence of a chemical divergence above the canopy, (ii) the existence of an $\mathrm{NO}_{2}$ emission flux from vegetation, (iii) the potential underestimation of the resistances used in the model, and (iv) the existence of an internal resistance for $\mathrm{NO}_{2}$ were explored.

The results did not suggest a considerable influence of chemical reactions above (and within) the canopy. In addition, the non-existence of a canopy compensation point for $\mathrm{NO}_{2}$ excluded the presence of an $\mathrm{NO}_{2}$ emission flux from vegetation. Moreover, the sensitivity of the model to the soil resistance to $\mathrm{NO}_{2}$ only accounted for a small difference between measured and modelled flux, which was $13 \%$ during daytime if the soil deposition was assumed to be zero. The other resistances were implicitly validated owing to the good agreement between measured and modelled $\mathrm{O}_{3}$ fluxes.

Consequently, only the existence of an internal resistance limiting $\mathrm{NO}_{2}$ stomatal uptake could explain the overestimation by the Surfatm model. The median internal resistance for $\mathrm{NO}_{2}$ was estimated from the $\mathrm{NO}_{2}$ flux measurements and from the modelled resistances to be about $300 \mathrm{~s} \mathrm{~m}^{-1}$, while the median for the stomatal resistance was only around $100 \mathrm{~s} \mathrm{~m}^{-1}$ during daytime. Consequently, the internal resistance represented between 50 and $90 \%$ of the total leaf resistance.

This study proved the existence of a large and significant internal resistance for $\mathrm{NO}_{2}$ for the grass species present at the meadow. For the first time, this type of investigation was made without an alteration of the microclimatological conditions that may occur when using the chamber method. This topic is particularly relevant for estimating dry deposition of $\mathrm{NO}_{2}$ over terrestrial ecosystems. An internal resistance is currently not taken into account in global models such as the EMEP model (Tsyro, 2001; Simpson et al., 2003) or the MOZART model (Horovitz et al., 2003), or strongly underestimated such as in the MATCH-MPIC model, in which the internal resistance is assumed to be half of the leaf stomatal resistance (Ganzeveld and Lelieveld, 1995; Shepon et al., 2007). These issues could lead to a large overestimation of the terrestrial $\mathrm{NO}_{2}$ sink. Nevertheless, further studies at other ecosystems are required to establish a parameterization of the internal resistance as a function of vegetation type that can be implemented in global chemistry and transport models.

Acknowledgements. The authors gratefully acknowledge financial support by the German Research Foundation (DFG project SALSA, ME 2100/1-1) and by the Max Planck Society. We are indebted to the German Meteorological Service (DWD) for a fruitful collaboration. We thank Graf (owner of the meadow), A. Thielmann, M. Welling, V. Wolff, K. Staudt, L. Pfannkuch, M. Scheibe and the Schindler family for their help and support during the field measurements.

The service charges for this open access publication have been covered by the Max Planck Society.

Edited by: X. Wang

\section{References}

Ainsworth, E. A.: Rice production in a changing climate: a metaanalysis of responses to elevated carbon dioxide an elevated ozone concentration, Glob. Change. Biol., 14, 1642-1650, 2008.

Almeida, E., Marracos, M., Morcillo, M., and Rosales, B.: Atmospheric corrosion of mild steel. Part I - Rural and urban atmosphere, Mater. Corros., 51, 859-864, 2000.

Altimir, N., Kolari, P., Tuovinen, J.P., Vesala, T., Bäck, J., Suni, T., Kulmala, M., and Hari, P.: Foliage surface ozone deposition: a role for surface moisture?, Biogeosciences., 3, 209-229, 2006.

Atkinson, R., Baulch, D. L., Cox, R. A., Crowley, J. N., Hampson, R. F., Hynes, R. G., Jenkin, M. E., Rossi, M. J., and Troe, J.: Evaluated kinetic and photochemical data for atmospheric chemistry: Volume I - gas phase reactions of Ox, HOx, NOx and SOx species, Atmos. Chem. Phys., 4, 1461-1738, doi:10.5194/acp-41461-2004, 2004.

Atkinson, R. and Arey, J.: Gas-phase tropospheric chemistry of biogenic volatile organic compounds: a review, Atmos. Environ., 37, S197-S219, 2003.

Aubinet, M., Grelle, A., Ibrom, A., Rannik, U., Moncrieff, J., Foken, T., Kowalski, A.S., Martin, P.H., Berbigier, P., Bernhofer, 
C., Clement, R., Elbers, J., Granier, A., Grunwald, T., Morgenstern, K., Pilegaard, K., Rebmann, C., Snijders, W., Valentini, R., and Vesala, T.: Estimates of the annual net carbon and water exchange of forests: The EUROFLUX methodology, Adv. Ecol. Res., 30, 113-175, 2000.

Aubinet, M., Vesala, T., and Papale, D.: Eddy covariance: A practical guide to measurement and data analysis, Springer, Dordrecht, Heidelberg, London, New York, p. 438, 2012.

Avnery, S., Mauzerall, D. L., Liu, J., and Horowitz, L. W.: Global crop yield reductions due to surface ozone exposure: 1. Year 2000 crop production losses and economic damage. Atmos. Environ., 45, 2284-2296, 2011a.

Avnery, S., Mauzerall, D. L., Liu, J., and Horowitz, L. W.: Global crop yield reductions due to surface ozone exposure: 2. Year 2030 potential crop production losses and economic damage under two scenarios of $\mathrm{O}_{3}$ pollution, Atmos. Environ., 45, 22972309, 2011b.

Baldocchi, D. D., Falge, E., Gu, L., Olson, R., Hollinger, D., Running, S., Anthoni, P., Bernhofer, C., Davis, K., Evans, R., Fuentes, J., Goldstein, A., Katul, G., Law, B., Lee, X., Malhi, Y., Meyers, T., Munger, W., Oechel, W., Paw U, K. T., Pilegaard, K., Schmid, H. P., Valentini, R., Verma, S., Vesala, T., Wilson, K., and Wofsy, S.: FLUXNET: A New Tool to Study the Temporal and Spatial Variability of Ecosystem-Scale Carbon Dioxide, Water Vapor and Energy Flux Densities, B. Am. Meteorol. Soc., 82, 2415-2434, 2001.

Bamberger, I., Hörtnagl, L., Schnitzhofer, R., Graus, M., Ruuskanen, T. M., Müller, M., Dunkl, J., Wohlfahrt, G., and Hansel, A.: BVOC fluxes above mountain grassland, Biogeosciences, 7, 1413-1424, doi:10.5194/bg-7-1413-2010, 2010.

Bargsten, A., Falge, E., Pritsch, K., Huwe, B., and Meixner, F. X.: Laboratory measurements of nitric oxide release from forest soil with a thick organic layer under different understory types, Biogeosciences, 7, 1425-1441, doi:10.5194/bg-7-1425-2010, 2010.

Beauchamp, J., Wisthaler, A., Hansel, A., Kleist, E., Miebach, M., Niinemets, U., Schurr, U., and Wildt, J.: Ozone induced emissions of biogenic voc from tobacco: Relationships between ozone uptake and emission of lox products, Plant Cell Environ., 28, 1334-1343, 2005.

Beier, N. and Schneewind, R.: Chemical reactions of gases in tubes of probing systems and their influence on measured concentrations, Ann. Geophys-Atm. Hydr., 9, 703-707, 1991.

Boyce, A., Nord, A. G., and Tronner, K.: Atmospheric bronze and copper corrosion as an environmental indicator, Water. Air. Soil. Poll., 127, 193-205, 2001.

Breuninger, C., Oswald, R., Kesselmeier, J., and Meixner, F.X.: The dynamic chamber method: trace gas exchange fluxes $\left(\mathrm{NO}, \mathrm{NO}_{2}\right.$, $\mathrm{O}_{3}$ ) between plants and the atmosphere in the laboratory and in the field, Atmos. Meas. Tech., 5, 955-989, 2012,

http://www.atmos-meas-tech.net/5/955/2012/.

Chaparro-Suarez, I. G., Meixner, F. X., and Kesselmeier, J.: Nitrogen dioxide $\left(\mathrm{NO}_{2}\right)$ uptake by vegetation controlled by atmospheric concentrations and plant stomatal aperture, Atmos. Environ., 45, 5742-5750, 2011.

Choudhury, B. J. and Monteith, J. L.: A four-layer model for the heat budget of homogeneous land surfaces, Q. J. Roy. Meteorol. Soc., 114, 373-398, 1988.

Coyle, M., Smith, R. I., Stedman, J. R., Weston, K. J., and Fowler, D.: Quantifying the spatial distribution of surface ozone concen- tration in the UK, Atmos. Environ., 36, 1013-1024, 2002.

Crutzen, P. J.: The influence of nitrogen oxides on the atmospheric ozone content, Q. J. Roy. Meteor. Soc., 96, 320-325, 1970.

Crutzen, P. J.: The role of $\mathrm{NO}$ and $\mathrm{NO}_{2}$ in the chemistry of the troposphere and stratosphere, Annu. Rev. Earth. Pl. Sc., 7, 443472, 1979.

Crutzen, P. J.: Atmospheric interactions of homogeneous gas reaction of $\mathrm{C}, \mathrm{N}$, and $\mathrm{S}$ containing compounds, in: The major biogeochemical cycles and their interactions, edited by: Bolin, B. and Cook, R. B., Wiley, New York, 219-235, 1983.

Damköhler, G.: Der Einfluss der Turbulenz auf die Flammengeschwindigkeit in Gasgemischen, Zeitschrift für Elektrochemie und Angewandte Physikalische Chemie, 46, 601-652, 1940.

Dari-Salisburgo, C., Di Carlo, P., Giammaria, F., Kajii, Y., and D'Altorio, A.: Laser induced fluorescence instrument for $\mathrm{NO}_{2}$ measurements: Observations at a central Italy background site, Atmos. Environ., 43, 970-977, 2009.

De Arellano, J. V. G. and Duynkerke, P. G.: Influence of chemistry on the flux-gradient relationships for the $\mathrm{NO}-\mathrm{O}_{3}-\mathrm{NO}_{2}$ system, Bound. Lay. Meteorol., 61, 375-387, 1992.

Desjardins, R. L., Macpherson, J. I., Schuepp, P. H., and Karanja, F.: An Evaluation of Aircraft Flux Measurements of CO2, WaterVapor and Sensible Heat, Bound. Lay. Meteorol., 47, 55-69, 1989.

Dolman, A. J., Noilhan, J., Durand, P., Sarrat, C., Brut, A., Piguet, B., Butet, A., Jarosz, N., Brunet, Y., Loustau, D., Lamaud, E., Tolk, L., Ronda, R., Miglietta, F., Gioli, B., Magliulo, V., Esposito, M., Gerbig, C., Körner, S., Glademard, P., Ramonet, M., Ciais, P., Neininger, B., Hutjes, R.W.A., Elbers, J. A., Macatangay, R., Schrems, O., Pérez-Landa, G., Sanz, M. J., Scholz, Y., Facon, G., Ceschia, E., and Beziat, P.: The CarboEurope regional experiment strategy, B. Am. Meteorol. Soc., 87, 13671379, 2006.

Dunlea, E. J., Herndon, S. C., Nelson, D. D., Volkamer, R. M., San Martini, F., Sheehy, P. M., Zahniser, M. S., Shorter, J. H., Wormhoudt, J. C., Lamb, B. K., Allwine, E. J., Gaffney, J. S., Marley, N. A., Grutter, M., Marquez, C., Blanco, S., Cardenas, B., Retama, A., Ramos Villegas, C. R., Kolb, C. E., Molina, L. T., and Molina, M. J.: Evaluation of nitrogen dioxide chemiluminescence monitors in a polluted urban environment, Atmos. Chem. Phys., 7, 2691-2704, doi:10.5194/acp-7-2691-2007, 2007.

Duyzer, J.H., Deinum, G., and Baak, J.: The interpretation of measurements of surface exchange of nitrogen oxides: correction for chemical reactions, Philos. T. Roy. Soc. A., 351, 231-248, 1995.

Dyer, A. J. and Hicks, B. B.: Flux-profile relationship in the constant flux layer, Q. J. Roy. Meteor. Soc., 96, 715-721, 1970.

Eller, A. S. D. and Sparks, J. D.: Predicting leaf-level fluxes of $\mathrm{O}_{3}$ and $\mathrm{NO}_{2}$ : the relative roles of diffusion and biochemical processes, Plant. Cell. Environ., 29, 1742-1750, 2006.

Emberson, L. D., Ashmore, M. R., Cambridge, H. M., Simpson, D., and Tuovinen, J. P.: Modelling stomatal ozone flux across Europe, Environ. Pollut., 109, 403-413, 2000.

Erisman, J. W., Van Pul, A., and Wyers, P.: Parameterization of surface resistance for the quantification of atmospheric deposition of acidifying pollutants and ozone, Atmos. Environ., 28, 25952607, 1994.

Eugster, W. and Hesterberg, R.: Transfer resistances of NO2 determined from eddy correlation flux measurements over a litter 
meadow at a rural site on the Swiss plateau, Atmos. Environ., 30, 1247-1254, 1996.

Feig, G. T., Mamtimin, B., and Meixner, F. X.: Soil biogenic emissions of nitric oxide from a semi-arid savanna in South Africa, Biogeosciences, 5, 1723-1738, 2008, http://www.biogeosciences.net/5/1723/2008/.

Foken, T.: Micrometeorology, Springer, Verlag Berlin Heidelberg, p. 308, 2008.

Foken, T. and Wichura, B.: Tools for quality assessment of surfacebased flux measurements, Agr. Forest. Meteorol., 78, 83-105, 1996.

Foken, T., Göckede, M., Mauder, M., Mahrt, L., Amiro, B., and Munger, W.: Postfield data quality control, in: Handbook of Micrometeorology: A guide for surface flux measurements and analysis, edited by: Lee, X., Massman, W. J., and Law, B. E., Kluwer Academic Publishers, 181-208, 2004.

Foken, T., Aubinet, M., and Leuning R: The eddy covariance method, in: Eddy Covariance: A Practical Guide to Measurement and Data Analysis, edited by: Aubinet, M., Vesala., T., and Papale, D., Springer, Dordrecht, Heidelberg, London, New York, 1-19, 2012a.

Foken, T., Meixner, F. X., Falge, E., Zetzsch, C., Serafimovich, A., Bargsten, A., Behrendt, T., Biermann, T., Breuninger, C., Dix, S., Gerken, T., Hunner, M., Lehmann-Pape, L., Hens, K., Jocher, G., Kesselmeier, J., Lüers, J., Mayer, J.-C., Moravek, A., Plake, D., Riederer, M., Rütz, F., Scheibe, M., Siebicke, L., Sörgel, M., Staudt, K., Trebs, I., Tsokankunku, A., Welling, M., Wolff, V., and Zhu, Z.: Coupling processes and exchange of energy and reactive and non-reactive trace gases at a forest site - results of the EGER experiment, Atmos. Chem. Phys., 12, 1923-1950, doi:10.5194/acp-12-1923-2012, 2012 b.

Forster, P., Ramaswamy, V., Artaxo, P., Berntsen, T., Betts, R., Fahey, D. W., Haywood, J., Lean, J., Lowe, D. C., Myhre, G., Nganga, J., Prinn, R., Raga, G., Schulz, M., and Van Dorland, R.: Changes in Atmospheric Constituents and in Radiative Forcing, in: Climate Change 2007: The Physical Basis, edited by: Solomon, S., Qin, D., Manning, M., Chen, Z., Marquis, M., Averyt, K. B., Tignor, M., and Miller, H. L., Contribution of Working Group I to Fourth Assessment Report of IPCC on Climate Change, Cambridge University Press, Cambridge, UK/NY, USA, 130-234, 2007.

Fowler, D., Pilegaard, K., Sutton, M. A., Ambus, P., Raivonen, M., Duyzer, J., Simpson, D., Fagerli, H., Fuzzi, S., Schjoerring, J.K., Granier, C., Neftel, A., Isaksen, I. S. A., Laj, P., Maione, M., Monks, P. S., Burkhardt, J., Daemmgen, U., Neirynck, J., Personne, E., Wichink-Kruit, R., Butterbach-Bahl, K., Flechard, C., Tuovinen, J. P., Coyle, M., Gerosa, G., Loubet, B., Altimir, N., Gruenhage, L., Ammann, C., Cieslik, S., Paoletti, E., Mikkelsen, T. N., Ro-Poulsen, H., Cellier, P., Cape, J. N., Horvath, L., Loreto, F., Niinemets, U., Palmer, P. I., Rinne, J., Misztal, P., Nemitz, E., Nilsson, D., Pryor, S., Gallagher, M. W., Vesala, T., Skiba, U., Brüggemann, N., Zechmeister-Boltenstern, S., Williams, J., O'Dowd, C., Facchini, M. C., de Leeuw, G., Flossman, A., Chaumerliac, N., and Erisman, J. W.: Atmospheric composition change: Ecosystemsatmosphere interactions, Atmos. Environ., 43, 5193-5267, 2009.

Galmarini, S., De Arellano, J. V. G., and Duyzer, J.: Fluxes of chemically reactive species inferred from mean concentration measurements, Atmos. Environ., 31, 2371-2374, 1997.
Ganzeveld, L. and Lelieveld, J.: Dry deposition parameterization in a chemistry general circulation model and its influence on the distribution of reactive trace gases, J. Geophys. Res., 100, 20999-21012, 1995.

Garland, J. A.: The dry deposition of sulphur dioxide to land and water surface. Proc. R. Soc. Lon. A. Mat., 354, 245-268, 1977.

Gerosa, G., Marzuoli, R., Cieslik, S., and Ballarin-Denti, A.: Stomatal ozone fluxes over barley field in Italy, "Effective exposure" as a possible link between exposure- and flux-based approaches, Atmos. Environ., 38, 2421-2432, 2004.

Geßler, A., Rienks, M., and Rennenberg, $\mathrm{H} .: \mathrm{NH}_{3}$ and $\mathrm{NO}_{2}$ fluxes between beech trees and the atmosphere - correlation with climatic and physiological parameters, New. Phytol., 147, 539-560, 2000.

Geßler, A., Rienks, M., and Rennenberg, H.: Stomatal uptake and cuticular adsorption contribute to dry deposition of $\mathrm{NH}_{3}$ and $\mathrm{NO}_{2}$ to needles of adult spruce (Picea abies) trees, New. Phytol., 156, 179-194, 2002.

Göckede, M., Rebmann, C., and Foken, T.: A combination of quality assessment tools for eddy covariance measurements with footprint modelling for the characterisation of complex sites, Agr. Forest. Meteorol., 127, 175-188, 2004.

Göckede, M., Markkanen, T., Hasager, C. B., and Foken, T.: Update of a footprint-based approach for the characterisation of complex measuring sites, Bound. Lay. Meteorol., 118, 635-655, 2006.

Goldstein, A. H. and Galbally, I. E.: Known and unexplored organic constituents in the earth's atmosphere, Environ. Sci. Technol., 41, 1514-1521, 2007.

Guenther, A., Geron, C., Pierce, T., Lamb, B., Harley, P., and Fall, R.: Natural emissions of non-methane volatile organic compounds, carbon monoxide, and oxide of nitrogen from North America, Atmos. Environ., 34, 2205-2230, 2000.

Güsten, H. and Heinrich, G.: On-line measurements of ozone surface fluxes: Part I. Methodology and instrumentation, Atmos. Environ., 30, 897-909, 1996.

Güsten, H., Heinrich, G., Schmidt, R. W. H., and Schurath, U.: A novel ozone sensor for direct eddy flux measurements, J. Atmos. Chem., 14, 73-84, 1992.

Gut, A., Scheibe, M., Rottenberger, S., Rummel, U., Welling, M., Ammann, C., Kirkman, G. A., Kuhn, U., Meixner, F. X., Kesselmeier, J., Lehmann, B. E., Schmidt, W., Müller, E., and Piedade, M. T. F.: Exchange fluxes of $\mathrm{NO}_{2}$ and $\mathrm{O}_{3}$ at soil and leaf surfaces in an Amazonian rain forest, J. Geophys. Res., 107, LBA27-1-LBA27-15, doi:10.1029/2001JD000654, 2002.

Hazucha, M. J. and Lefohn, A. S.: Nonlinearity in human health response to ozone: Experimental laboratory considerations, Atmos. Environ., 41, 4559-4570, 2007.

Hereid, D. P. and Monson, R. K.: Nitrogen oxide fluxes between corn (Zea mays L.) leaves and the atmosphere, Atmos. Environ., 35, 975-983, 2001.

Hicks, B. B., Baldocchi, D. D., Meyers, T. P., Hosker Jr., R. P., and Matt, D. R.: A preliminary multiple resistance routine for deriving dry deposition velocities from measured quantities, Water. Air. Soil. Pollut., 36, 311-330, 1987.

Hillstrom, M. L. and Lindroth, R. L.: Elevated atmospheric carbon dioxide and ozone alter forest insect abundance and community composition, Insect. Conserv. Diver., 1, 233-241, 2008.

Horowitz, L. Walters, S., Mauzerall, D. L., Emmons, L. K., Rasch, P. J., Granier, C., Tie, X., Lamarque, J-F., Schultz, M. G., Tyn- 
dall, G. S., Orlando, J. J., and Brasseur, G. P.: A global simulation of tropospheric ozone and related tracers: Description and evaluation of MOZART, version 2, J. Geophys. Res., 108, D24784, doi:10.1029/2002JD002853, 2003.

Hosaynali Beygi, Z., Fischer, H., Harder, H. D., Martinez, M., Sander, R., Williams, J., Brookes, D. M., Monks, P. S., and Lelieveld, J.: Oxidation photochemistry in the Southern Atlantic boundary layer: unexpected deviations of photochemical steady state, Atmos. Chem. Phys., 11, 8497-8513, doi:10.5194/acp-118497-2011, 2011.

$\mathrm{Hu}$, Y. and Sun., G.: Leaf nitrogen dioxide uptake coupling apoplastic chemistry, carbon/sulphur assimilation, and plant nitrogen status, Plant. Cell. Rep., 29, 1069-1077, 2010.

Johansson, C.: Pine forest: a negligible sink for atmospheric $\mathrm{NO}_{\mathrm{x}}$ in rural Sweden, Tellus B, 39, 426-438, 1987.

Karl, T., Guenther, A., Lindinger, C., Jordan, A., Fall, R., and Lindinger, W.: Eddy covariance measurements of oxygenated volatile organic compound fluxes from crop harvesting using a redesigned proton-transfer-reaction mass spectrometer, J. Geophys. Res., 106, 24157-24167, doi:10.1029/2000jd000112, 2001.

Kley, D. and McFarland, M.: Chemiluminescence detector for NO and $\mathrm{NO}_{2}$, Atmos. Technol., 12, 63-69, 1980.

Kowalski, S., Sartore, M., Burlett, R., Berbigier, P., and Loustau, D.: The annual carbon budget of a French pine forest (Pinus Pinaster) following harvest, Glob. Change. Biol., 9, 1051-1065, 2003.

Kowalski, S., Loustau, D., Berbigier, P., Manca, G., Tedeschi, V., Borghetti, M., Valentini, R., Kolari, P., Berniger, F., Rannik, U., Hari, P., Rayment, M., Mencuccini, M., Moncrieff, J., and Grace, J.: Paired comparison of carbon exchange between undisturbed and regenerating stands in four managed forests in Europe, Glob. Change. Biol., 10, 1707-1723, 2004.

Kramm, G., Beier, N., Foken, T., Müller, H., Schröder, P., and Seiler, W.: A SVAT Scheme for $\mathrm{NO}, \mathrm{NO}_{2}$ and $\mathrm{O}_{3}-$ Model Description and Test Results, Meteorol. Atmos. Phys., 61, 89-106, 1996.

Kramm, G., Müller, H., Fowler, D., Höfken, K., Meixner, F. X., and Schaller, E.: A Modified Profile Method for Determining the Vertical Fluxes of $\mathrm{NO}, \mathrm{NO}_{2}$, Ozone, and $\mathrm{HNO}_{3}$ in the Atmospheric Surface Layer, J. Atmos. Chem., 13, 265-288, 1991.

Lamaud, E., Loubet, B., Irvine, M., Stella, P., Personne, E., and Cellier, P.: Partitioning of ozone deposition over a developed maize crop between stomatal and non-stomatal uptakes, using eddycovariance flux measurements and modelling, Agr. Forest. Meteorol., 149, 1385-1386, 2009.

Laville, P., Flura, D., Gabrielle, B., Loubet, B., Fanucci, O., Rolland, M. N., and Cellier, P.: Characterisation of soil emissions of nitric oxide at field and laboratory scale using high resolution method, Atmos. Environ., 43, 2648-2658, 2009.

Lerdau, M. T., Munger, J. W., and Jacob, D. J.: The $\mathrm{NO}_{2}$ flux conundrum, Science, 289, 2291-2293, 2000.

Lenschow, D. H.: Reactive Trace Species in the Boundary Layer from a Micrometeorological Perpective, J. Meteorol. Soc. Jpn., 60, 472-480, 1982.

Lenschow, D. H. and Delany, A. C.: An analytic formulation for NO and $\mathrm{NO}_{2}$ flux profiles in the atmospheric surface layer, J. Atmos. Chem., 5, 301-309, 1987.

Levy, J. I., Chemerynski, S. M., and Sarnat, J. A.: Ozone exposure and mortality: an empiric Bayes metaregression analysis, Epi- demiology., 16, 458-468, 2005.

Loubet, B., Cellier, P., Milford, C., and Sutton, M. A.: A coupled dispersion and exchange model for short-range dry deposition of atmospheric ammonia, Q. J. Roy. Meteorol. Soc., 132, 1733$1763,2006$.

Ludwig, J., Meixner, F. X., Vogel, B., and Förstner, J.: Soil-air exchange of nitric oxide: An overview of processes, environmental factors, and modelling studies, Biogeochemistry, 52, 225-257, 2001.

Massman, W. J.: A review of the molecular diffusivities of $\mathrm{H}_{2} \mathrm{O}$, $\mathrm{CO}_{2}, \mathrm{CH}_{4}, \mathrm{CO}, \mathrm{O}_{3}, \mathrm{SO}_{2}, \mathrm{NH}_{3}, \mathrm{~N}_{2} \mathrm{O}, \mathrm{NO}$ and $\mathrm{NO}_{2}$ in air, $\mathrm{O}_{2}$ and $\mathrm{N}_{2}$ near STP, Atmos. Environ., 32, 1111-1127, 1998.

Massman, W. J.: Toward an ozone standard to protect vegetation based on effective dose: a review of deposition resistances and possible metric, Atmos. Environ., 38, 2323-2337, 2004.

Mayer, J.-C., Staudt, K., Gilge, S., Meixner, F. X., and Foken, T.: The impact of free convection on late morning ozone decreases on an Alpine foreland mountain summit, Atmos. Chem. Phys., 8 , 5941-5956, doi:10.5194/acp-8-5941-2008, 2008.

Mayer, J.-C., Bargsten, A., Rummel, U., Meixner, F. X., and Foken, T.: Distributed modified Bowen ratio method for surface layer fluxes of reactive and non-reactive trace gases, Agr. Forest. Meteorol., 151, 655-668, 2011.

Meixner, F. X.: Surface exchange of odd nitrogen oxides, Nova Acta Leoplodina, NF 70, 299-348, 1994.

Meixner, F. X., Fickinger, T., Marufu, L., Serca, D., Nathaus, F. J., Makina, E., Mukurumbira, L., and Andreae, M. O.: Preliminary results on nitric oxide emission from a southern African savanna ecosystem, Nutr. Cycl. Agroecosys., 48, 123-138, 1997.

Monteith, J. L.: Evaporation and surface temperature, Q. J. Roy. Meteorol. Soc., 107, 1-27, 1981.

Müller, J. B. A., Percival, C. J., Gallagher, M. W., Fowler, D., Coyle, M., and Nemitz, E.: Sources of uncertainty in eddy covariance ozone flux measurements made by dry chemiluminescence fast response analysers, Atmos. Meas. Tech., 3, 163-176, 2010, http://www.atmos-meas-tech.net/3/163/2010/.

Oncley, S. P.: Flux parameterization techniques in the atmospheric surface layer, Dissertation at the University of California, Irvine CA, 202 pp., 1989.

Paoletti, E.: Ozone slows stomatal response to light and leaf wounding in a Mediterranean evergreen broadleaf, Arbustus unedo, Environ. Pollut., 134, 439-445, 2005.

Pape, L., Ammann, C., Nyfeler-Brunner, A., Spirig, C., Hens, K., and Meixner, F. X.: An automated dynamic chamber system for surface exchange measurement of non-reactive and reactive trace gases of grassland ecosystems, Biogeosciences, 6, 405429, doi:10.5194/bg-6-405-2009, 2009.

Parrish, D. D. and Fensenfeld, F. C.: Methods for gas-phase measurements of ozone, ozone precursors and aerosol precursors, Atmos. Environ., 34, 1921-1957, 2000.

Payne, R. J., Stevens, C. J., Dise, N. B., Gowing, D. J., Pilkington, M. G., Phoenix, G. K., Emmett, B. A., and Ashmore, M. R.: Impacts of atmospheric pollution on the plant communities of British acid grasslands, Environ. Pollut., 159, 2602-2608, 2011.

Personne, E., Loubet, B., Herrmann, B., Mattsson, M., Schjoerring, J. K., Nemitz, E., Sutton, M. A., and Cellier, P.: SURFATM-NH3: a model combining the surface energy balance and bi-directional exchanges of ammonia applied at the field scale, Biogeosciences, 6, 1371-1388, doi:10.5194/bg-6-1371-2009, 2009. 
Pilegaard, K., Hummelshoj, P., and Jensen, N.O.: Fluxes of ozone and nitrogen dioxide measured by eddy correlation over a harvested wheat field, Atmos. Environ., 32, 1167-1177, 1998.

Pinto, M., Merino, P., del Prado, A., Estavillo, J. M., Yamulki, S., Gebauer, G., Piertzak, S., Lauf, J., and Oenema, O.: Increased emissions of nitric oxide and nitrous oxide following tillage of a perennial pasture, Nutr. Cy. Agroecosys., 70, 13-22, 2004.

Pollack, I. B., Lerner, B. M., and Ryerson, T. B.: Evaluation of ultraviolet light-emitting diodes for detection of atmospheric $\mathrm{NO}_{2}$ by photolysis - chemiluminescence, J. Atmos. Chem., 65, 111-125, 2011.

Raupach, M. R., Finnigan, J. J., and Brunet, Y.: Coherent eddies and turbulence inside vegetation canopies. The mixing layer analogy, Bound. Lay. Meteorol., 78, 351-382, 1996.

Remde, A. and Conrad, R.: Role of nitrification and denitrification for NO metaboloism in soil, Biogeochemistry, 12, 189-205, 1991.

Remde, A., Slemr, F., and Conrad, R.: Microbial production and uptake of nitric oxide in soil, FEMS. Microbiol. Ecol., 62, 221230, 1989.

Remde, A., Ludwig, J., Meixner, F. X., and Conrad, R.: A study to explain the emission of nitric oxide from a marsh soil, J. Atmos. Chem., 17, 249-275, 1993.

Ridley, B. A., Carroll, M. A., Torres, A. L., Condon, E. P., Sachse, G. W., Hill, G. F., and Gregory, G. L.: An intercomparison of results from ferrous sulfate and photolytic converter techniques for measurements of No-Chi Made during the Nasa Gte Cite-1 Aircraft Program, J. Geophys. Res. Atmos., 93, 15803-15811, 1988.

Rondón, A., Johansson, C., and Granat, L.: Dry deposition of nitrogen dioxide and ozone to coniferous forests, J. Geophys. Res., 98, 5159-5172, 1993.

Rummel, U., Ammann, C., Kirkman, G. A., Moura, M. A. L., Foken, T., Andreae, M. O., and Meixner, F. X.: Seasonal variation of ozone deposition to a tropical rain forest in southwest Amazonia, Atmos. Chem. Phys., 7, 5415-5435, doi:10.5194/acp-75415-2007, 2007.

Running, S. W., Baldocchi, D. D., Turner, D. P., Gower, S. T., Bakwin, P. S., and Hibbard, K. A.: A global terrestrial monitoring network integrating tower fluxes, flask sampling, ecosystem modelling and EOS satellite data, Remote. Sens. Environ., 70, 108-127, 1999.

Ruuskanen, T. M., Müller, M., Schnitzhofer, R., Karl, T., Graus, M., Bamberger, I., Hörtnagl, L., Brilli, F., Wohlfahrt, G., and Hansel, A.: Eddy covariance VOC emission and deposition fluxes above grassland using PTR-TOF, Atmos. Chem. Phys., 11, 611-625, doi:10.5194/acp-11-611-2011, 2011.

Segschneider, H. J., Wildt, J., and Förstel, H.: Uptake of ${ }^{15} \mathrm{NO}_{2}$ by sunflower (Helianthus annuus) during exposures in light and darkness: quantities, relationship to stomatal aperture and incorporation into different nitrogen pools within the plant, New. Phytol., 131, 109-119, 1995.

Shepon, A., Gildor, H., Labrador, L. J., Butler, T., Ganzeveld., L. N., and Lawrence, M. G.: Global reactive nitrogen deposition from lightning $\mathrm{NO}_{\mathrm{x}}$, J. Geophys. Res., 112, D06304, doi:10.1029/2006JD007458, 2007.

Shuttelworth, W. J. and Wallace, S. J.: Evaporation from sparse crop - An energy combination theory, Q. J. Roy. Meteorol. Soc., 111, 477-507, 1985.
Simpson, D., Fagerli, H., Jonson, J., Tsyro, S., Wind, P., and Tuovinen, J. P.: The EMEP unified Eulerian model. Model description. EMEP MSC-W Report 1/2003, The Norwegian Meteorological Institute, Oslo, Norway, 2003.

Skiba, U., Drewer, J., Tang, Y. S., van Dijk, N., Helfter, C., Nemitz, E., Famulari, D., Cape, J. N., Jones, S. K., Twigg, M., Pihlatie, M., Vesala, T., Larsen, K. S., Carter, M. S., Ambus, P., Ibrom, A., Beier, C., Hensen, A., Frumau, A., Erisman, J. W., Brüggemann, N., Gasche, R., Butterbach-Bahl, K., Neftel, A., Spirig, C., Horvath, L., Freibauer, A., Cellier, P., Laville, P., Loubet, B., Magliulo, E., Bertolini, T., Seufert, G., Andersson, M., Manca, G., Laurila, T., Aurela, M., Lohila, A., Zechmeister-Boltenstern, S., Kitzler, B., Schaufler, G., Siemens, J., Kindler, R., Flechard, C., and Sutton, M. A.: Biosphere-atmosphere exchange of reactive nitrogen and greenhouse gases at the NitroEurope core flux measurements sites: Measurement strategy and first data sets, Agr. Ecosyst. Environ., 133, 139-149, 2009.

Sparks, J. P., Monson, R. K., Sparks, K. L., and Lerdau, M. L.: Leaf uptake of nitrogen dioxide $\left(\mathrm{NO}_{2}\right)$ in a tropical wet forest: implications for tropospheric chemistry, Oecologia., 127, 214221, 2001.

Spirig, C., Neftel, A., Ammann, C., Dommen, J., Grabmer, W., Thielmann, A., Schaub, A., Beauchamp, J., Wisthaler, A., and Hansel, A.: Eddy covariance flux measurements of biogenic VOCs during ECHO 2003 using proton transfer reaction mass spectrometry, Atmos. Chem. Phys., 5, 465-481, doi:10.5194/acp-5-465-2005, 2005.

Stella, P., Loubet, B., Lamaud, E., Laville, P., and Cellier, P.: Ozone deposition onto bare soil: a new parameterisation, Agr. Forest. Meteorol., 151, 669-681, 2011a.

Stella, P., Personne, E., Loubet, B., Lamaud, E., Ceschia, E., Béziat, P., Bonnefond, J. M., Irvine, M., Keravec, P., Mascher, N., and Cellier, P.: Predicting and partitioning ozone fluxes to maize crops from sowing to harvest: the Surfatm-O3 model, Biogeosciences, 8, 2869-2886, doi:10.5194/bg-8-2869-2011, $2011 \mathrm{~b}$.

Stella, P., Loubet, B., Laville, P., Lamaud, E., Cazaunau, M., Laufs, S., Bernard, F., Grosselin, B., Mascher, N., Kurtenbach, R., Mellouki, A., Kleffmann, J., and Cellier, P.: Comparison of methods for the determination of $\mathrm{NO}-\mathrm{O}_{3}-\mathrm{NO}_{2}$ fluxes and chemical interactions over a bare soil, Atmos. Meas. Tech., 5, 1241-1257, doi:10.5194/amt-5-1241-2012, 2012.

Stull, R. B.: An introduction to boundary layer meteorology, Vol. 1. Kluwer Academic Publishers, Dordrecht, the Netherlands, 1989.

Teklemariam, T. A., and Sparks, J. P.: Leaf fluxes of $\mathrm{NO}$ and $\mathrm{NO}_{2}$ in four herbaceous plant species: the role of ascorbic acid, Atmos. Environ., 40, 2235-2244, 2006.

Trebs, I., Bohn, B., Ammann, C., Rummel, U., Blumthaler, M., Königstedt, R., Meixner, F. X., Fan, S., and Andreae, M. O.: Relationship between the $\mathrm{NO} 2$ photolysis frequency and the solar global irradiance, Atmos. Meas. Tech., 2, 725-739, doi:10.5194/amt-2-725-2009, 2009.

Tsyro, S.: Description of the Lagrangian acid deposition model, Technical report, EMEP, 2001.

Vickers, D. and Mahrt, L.: Quality control and flux sampling problems for tower and aircraft data, J. Atmos. Ocean. Tech., 14, 512526, 1997.

Walton, S., Gallagher, M. W., and Duyzer, J. H.: Use of a detailed model to study the exchange of $\mathrm{NO}_{\mathrm{x}}$ and $\mathrm{O}_{3}$ above and below a deciduous canopy, Atmos. Environ., 31, 2915-2931, 1997. 
Warneck, P.: Chemistry of the Natural Atmosphere, $2^{\text {nd }}$ Edition, International Geophysics Series. Academic Press Inc., San Diego, USA, 2000.

Webb, E. K., Pearman, G. I., and Leuning, R.: Correction of flux measurements for density effects due to heat and water-vapor transfer, Q. J. Roy. Meteor. Soc., 106, 85-100, 1980.

Weber, P. and Rennenberg, H.: Dependency of nitrogen dioxide $\left(\mathrm{NO}_{2}\right)$ fluxes to wheat (Triticum aestivum L.) leaves from $\mathrm{NO}_{2}$ concentration, light intensity, temperature and relative humidity determined from controlled dynamic chamber experiments, Atmos. Environ., 30, 3001-3009, 1996.
Wesely, M. L.: Parameterization of surface resistances to gaseous dry deposition in regional-scale numerical models, Atmos. Environ., 23, 1293-1304, 1989.

Wesely, M. L. and Hicks, B. B.: A review of the current status of knowledge on dry deposition, Atmos. Environ., 34, 2261-2282, 2000.

Wilczak, J. M., Oncley, S. P., and Stage, S. A.: Sonic anemometer tilt correction algorithms, Bound. Lay. Meteorol., 99, 127-150, 2001.

Zhang, L., Brook, J. R., and Vet, R.: On ozone dry deposition with emphasis on non-stomatal uptake and wet canopies, Atmos. Environ., 36, 4787-4799, 2002. 